\title{
Benthic Vertical Hydraulic Gradients in Upper Klamath Lake, Oregon, 2017
}

Scientific Investigations Report 2020-5029 
Cover: Water-level monitoring equipment deployed at site ON03 in Upper Klamath Lake, Oregon, viewed looking northwest. (Photograph taken by Jim Kuwabara, U.S. Geological Survey, August 2, 2017.) 


\section{Benthic Vertical Hydraulic Gradients in Upper Klamath Lake, Oregon, 2017}

By Nicholas T. Corson-Dosch

Scientific Investigations Report 2020-5029 


\title{
U.S. Department of the Interior \\ DAVID BERNHARDT, Secretary
}

\author{
U.S. Geological Survey \\ James F. Reilly II, Director
}

U.S. Geological Survey, Reston, Virginia: 2020

For more information on the USGS - the Federal source for science about the Earth, its natural and living resources, natural hazards, and the environment—visit https://www.usgs.gov or call 1-888-ASK-USGS.

For an overview of USGS information products, including maps, imagery, and publications, visit https://store.usgs.gov/.

Any use of trade, firm, or product names is for descriptive purposes only and does not imply endorsement by the U.S. Government.

Although this information product, for the most part, is in the public domain, it also may contain copyrighted materials as noted in the text. Permission to reproduce copyrighted items must be secured from the copyright owner.

Suggested citation:

Corson-Dosch, N.T., 2020, Benthic vertical hydraulic gradients in Upper Klamath Lake, Oregon, 2017: U.S. Geological Survey Scientific Investigations Report 2020-5029, 22 p., https://doi.org/10.3133/sir20205029.

ISSN 2328-0328 (online) 


\section{Contents}

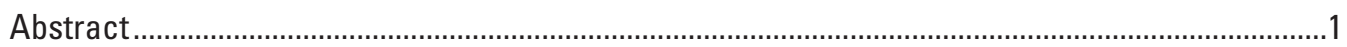

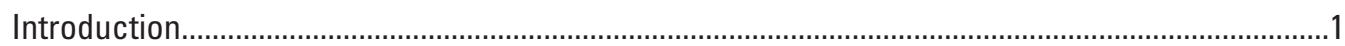

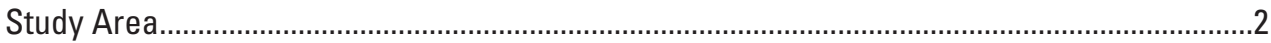

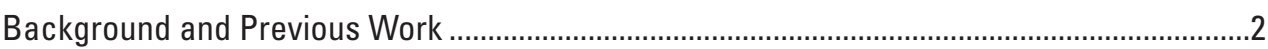

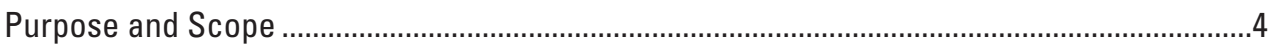

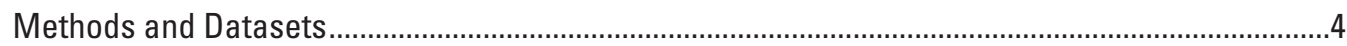

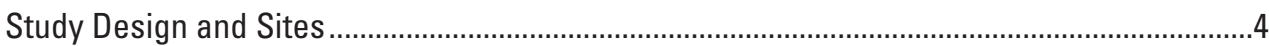

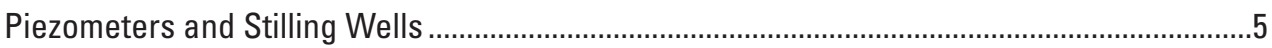

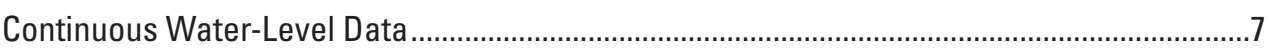

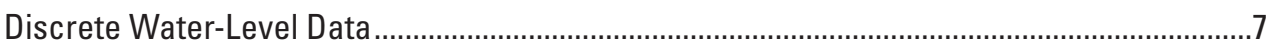

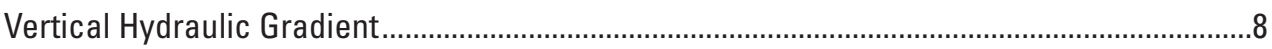

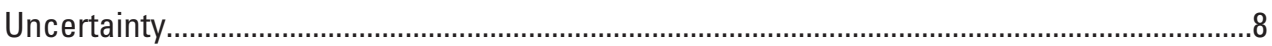

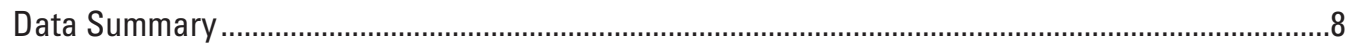

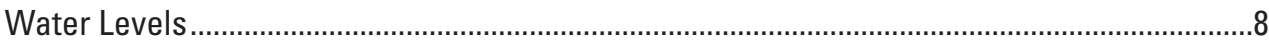

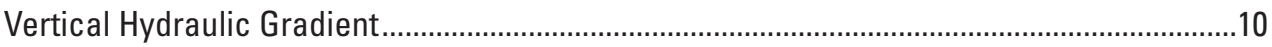

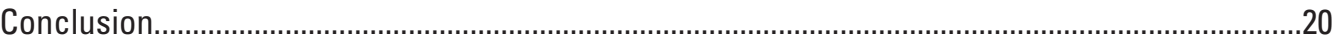

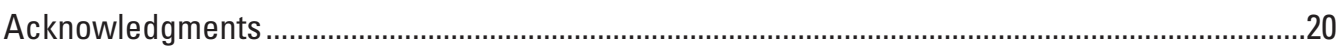

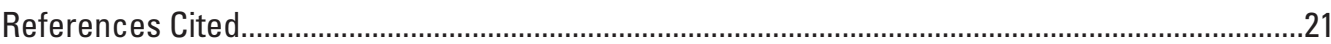

\section{Figures}

1. Map showing locations of groundwater piezometer and stilling well paired sets at 10 sites on Upper Klamath Lake, Oregon, 2017.

2. Schematic diagram of the groundwater piezometer and lake stilling well apparatus deployed at 10 locations and detail view of the recording pressure transducer configuration with the common measuring point for groundwater and lake depth-to-water measurements...

3. Graph showing barometric pressure at the Rocky Point gage, Upper Klamath Lake, Oregon, 2017.

4. Graphs showing measured groundwater and lake depth to water below the measuring point and calculated vertical hydraulic gradient at site SPR in Upper Klamath Lake, Oregon, 2017.

5. Graphs showing groundwater and lake depth to water below the measuring point and calculated vertical hydraulic gradient at site LNO1 in Upper Klamath Lake, Oregon, 2017.

6. Graphs showing groundwater and lake depth to water below measuring the point and vertical hydraulic gradient (VHG) at site ON02 in Upper Klamath Lake, Oregon, 2017

7. Graphs showing groundwater and lake depth to water below the measuring point and vertical hydraulic gradient (VHG) at site ONO3 in Upper Klamath Lake, Oregon, 2017

8. Graphs showing groundwater and lake depth to water below the measuring point and vertical hydraulic gradient at site LC01 in Upper Klamath Lake, Oregon, 2017 


\section{Figures-Continued}

9. Graphs showing groundwater and lake depth to water below the measuring point and vertical hydraulic gradient at site LCO3 in Upper Klamath Lake, Oregon,

2017

10. Graphs showing groundwater and lake depth to water below the measuring point and vertical hydraulic gradient (VHG) at site OC02 in Upper Klamath Lake, Oregon, 2017

11. Graphs showing groundwater and lake depth to water below the measuring point and vertical hydraulic gradient (VHG) at site LS01 in Upper Klamath Lake, Oregon, 2017

12. Graphs showing groundwater and lake depth to water below the measuring point and vertical hydraulic gradient (VHG) at site OS03 in Upper Klamath Lake, Oregon, 2017

13. Graphs showing groundwater and lake depth to water below the measuring point and vertical hydraulic gradient (VHG) at site ONO1 in Upper Klamath Lake, Oregon, 2017

\section{Tables}

1. Site locations and deployment durations, Upper Klamath Lake, Oregon, 2017

2. Continuous data collection and mean vertical hydraulic gradient (VHG) during each week and during the study period at each site, Upper Klamath Lake, Oregon, 2017 


\section{Conversion Factors}

U.S. customary units to International System of Units

\begin{tabular}{|c|c|c|}
\hline Multiply & By & To obtain \\
\hline \multicolumn{3}{|c|}{ Length } \\
\hline inch (in.) & 2.54 & centimeter $(\mathrm{cm})$ \\
\hline inch (in.) & 25.4 & millimeter (mm) \\
\hline foot $(\mathrm{ft})$ & 0.3048 & $\operatorname{meter}(\mathrm{m})$ \\
\hline mile (mi) & 1.609 & kilometer (km) \\
\hline \multicolumn{3}{|c|}{ Area } \\
\hline square foot $\left(\mathrm{ft}^{2}\right)$ & 929.0 & square centimeter $\left(\mathrm{cm}^{2}\right)$ \\
\hline square foot $\left(\mathrm{ft}^{2}\right)$ & 0.09290 & square meter $\left(\mathrm{m}^{2}\right)$ \\
\hline square mile $\left(\mathrm{mi}^{2}\right)$ & 259.0 & hectare (ha) \\
\hline square mile $\left(\mathrm{mi}^{2}\right)$ & 2.590 & square kilometer $\left(\mathrm{km}^{2}\right)$ \\
\hline \multicolumn{3}{|c|}{ Volume } \\
\hline ounce, fluid (fl. oz) & 0.02957 & liter $(\mathrm{L})$ \\
\hline pint (pt) & 0.4732 & liter (L) \\
\hline quart (qt) & 0.9464 & liter (L) \\
\hline gallon (gal) & 3.785 & liter (L) \\
\hline cubic inch $\left(\right.$ in $\left.^{3}\right)$ & 0.01639 & liter $(\mathrm{L})$ \\
\hline cubic foot $\left(\mathrm{ft}^{3}\right)$ & 28.32 & cubic decimeter $\left(\mathrm{dm}^{3}\right)$ \\
\hline cubic foot $\left(\mathrm{ft}^{3}\right)$ & 0.02832 & cubic meter $\left(\mathrm{m}^{3}\right)$ \\
\hline \multicolumn{3}{|c|}{ Flow rate } \\
\hline cubic foot per second ( $\left.\mathrm{ft}^{3} / \mathrm{s}\right)$ & 0.02832 & cubic meter per second $\left(\mathrm{m}^{3} / \mathrm{s}\right)$ \\
\hline
\end{tabular}

\section{Datum}

Horizontal coordinate information is referenced to the North American Datum of 1983 (NAD 83).

\section{Abbreviations}

MP measuring point

UKL Upper Klamath Lake

USGS U.S. Geological Survey

VHG vertical hydraulic gradient 



\title{
Benthic Vertical Hydraulic Gradients in Upper Klamath Lake, Oregon, 2017
}

\author{
By Nicholas T. Corson-Dosch
}

\section{Abstract}

Groundwater piezometers and lake stilling wells were deployed as paired sets at 10 locations in Upper Klamath Lake in south-central Oregon from May to October 2017 to measure hydraulic heads in and beneath the lake. Continuous water-level data from piezometers and stilling wells were then used to calculate the vertical hydraulic gradient (VHG) across the sediment-water interface to determine the direction and relative magnitude of the movement of water between the lake and underlying sediments. Over the study period, heads in lake-bed sediments closely tracked lake levels, both decreasing from spring into autumn. Instantaneous VHG was highly dynamic at all sites and exhibited high-frequency (less than 1 day to less than 1 hour) variations in magnitude and direction. Instantaneous and weekly mean VHG values often exceeded, but were commonly within, the range of measurement uncertainty (VHG less than +0.009 foot per foot [ft/ $\mathrm{ft}$ ] and greater than $-0.009 \mathrm{ft} / \mathrm{ft}$ ). 63 percent of instantaneous VHG values and 66 percent of weekly mean VHG values were within this range. Study period mean VHG was within measurement uncertainty at seven of the nine sites that had continuous water-level data, but two littoral sites (LC03 and LS01) had positive (upward) values greater than measurement uncertainty and are likely locations of vertical groundwater seepage. Data collected in this study provide new information about the hydraulic conditions at the sediment-water interface in UKL and demonstrate that sediment-groundwater exchange in UKL is spatially and temporally heterogeneous.

\section{Introduction}

Upper Klamath Lake (UKL), in south-central Oregon, is naturally eutrophic ${ }^{1}$ and receives nutrients from internal (groundwater inflow, lakebed sediment) and external (tributary

\footnotetext{
1Eutrophication is a natural process that results from an overabundance of nutrients - primarily nitrogen and phosphorus - in lakes or other bodies of water. Algae feed on the nutrients, and proliferate in blooms - growing, spreading, and turning the water green. When the algae die, they are decomposed by bacteria. This process consumes oxygen and can deplete dissolved oxygen levels in the water body creating a state of hypoxia.
}

streams, runoff, atmospheric deposition) sources (Oregon Department of Environmental Quality, 2002). Anthropogenic changes to the basin have increased nutrient delivery to UKL, and in recent decades, the lake has experienced annual cyanobacterial algal blooms during summer (Bortleson and Fretwell, 1993; Kann and others, 2015). UKL is now hypereutrophic (U.S. Fish and Wildlife Service, 2012). Algal blooms contribute to severe water-quality problems in UKL, including low and high dissolved-oxygen concentrations, high $\mathrm{pH}$, and high ammonia concentrations (Wood and others, 2006). These conditions stress endangered fish species in the lake (specifically short-nose suckers [Chasmistes brevirostris] and Lost River suckers [Deltistes luxatus]) and affect water quality downstream in the Klamath River (Saiki and others, 1999; Sullivan and others, 2013).

Understanding and addressing water-quality problems in UKL requires an accurate account of the flows of water and nutrients into and out of the lake. Previously published waterbalance estimates indicate that groundwater inflow to the lake represents about 15 percent of the total lake inflow (Hubbard, 1970; Bureau of Reclamation, 2005; Walker and others, 2012). An unknown proportion of this groundwater is from seepage through the lakebed, which could transport nutrients from the groundwater system to the lake water column. Kuwabara and others $(2009 ; 2016)$ suggest that groundwater inflow through lakebed sediments may be an important mechanism for lake nutrient loading. This concept is difficult to evaluate, however, because little is known about the distribution and magnitude of possible groundwater inflow, or about how inflow of solutes with groundwater may relate to algal bloom dynamics. Understanding and quantifying groundwater inflow into UKL is hampered by a lack of information on the controlling physical parameters such as vertical hydraulic gradients (VHG) and sediment hydraulic conductivity.

The U.S. Geological Survey (USGS) began a study in 2017 to collect information about vertical hydraulic gradients in UKL. Vertical hydraulic gradients were directly measured beneath UKL in spring and summer, the period when cyanobacterial blooms occur. Ten sites in UKL (fig. 1) were instrumented to measure shallow lakebed groundwater levels and lake water levels during spring through autumn 2017. Groundwater and lake water-level data were used to calculate VHG at these locations. VHG can be used to characterize the direction and relative magnitude of groundwater-lake 
exchange at each site. Hydrologic data collected in the study and documented in this report can be used to refine UKL water and nutrient budgets and to better define the spatial and temporal distribution of groundwater-lake water exchange in UKL.

\section{Study Area}

UKL (fig. 1) is in south-central Oregon about 15 miles north of the Oregon-California border and 11 miles east of the Cascade Range crest. The lake is in the Klamath Graben, a down-dropped structural valley bounded by northwesttrending faults and steep, high escarpments. The UKL drainage basin is about 3,800 square miles $\left(\mathrm{mi}^{2}\right)$ and spans the boundary between the Cascade Range and the Basin and Range geologic provinces (Leonard and Harris, 1974). The geology of the basin is characterized by highly permeable volcanic rock and volcanically derived, phosphorus-rich soils (Wood and others, 2006; Gannett and others, 2007). UKL is underlain by thick accumulations of basin-fill deposits and lake sediments (clay, silt, sand and diatomite) estimated to be 1,300-4,000 feet (ft) thick (Gannett and others, 2012).

UKL is large, shallow, and relatively well mixed. The surface area of the lake ranges from about 100 to $140 \mathrm{mi}^{2}$ depending on lake stage (Hubbard, 1970; Johnson and others, 1985). The mean water depth in UKL is $9 \mathrm{ft}$, and about 90 percent of the lake is less than $12 \mathrm{ft}$ (Wood and others, 2006). The primary source of water to the lake is the Williamson River, which supplies about 46 percent of the total lake inflow (Johnson and others, 1985). UKL also receives water from other tributary streams, agricultural return flows, springs, precipitation, and direct groundwater seepage.

Although UKL is a natural water body, lake stage has been regulated since 1921, when Link River Dam was constructed at the lake's outlet. Since 2001, in accordance with the Endangered Species Act, the U.S. Bureau of Reclamation has been required to maintain lake elevations at certain levels to protect habitat for endangered fish species in UKL. At the same time, water must be released from UKL at the Link River Dam to achieve specified flows in the Klamath River for salmon, which are federally listed as a threatened species (National Research Council, 2008; Gannett and others, 2012). Water from UKL and the Upper Klamath River is also the primary supply for the Bureau of Reclamation Klamath Project, an irrigation system that provides water to approximately 375 $\mathrm{mi}^{2}$ of farm and ranch land in the Upper Klamath Basin (Wood and others, 2006). The combined effects of these uses, coupled with reduced summer inflow in tributaries and evapotranspiration from the lake surface, cause the lake elevation to decrease about $5 \mathrm{ft}$ from spring to autumn (Wood and others, 2006; Gannett and others, 2012).

The uplands surrounding UKL are recharge areas for the regional groundwater flow system. Groundwater head gradients to the north, east, and west of the lake slope toward UKL from the uplands (Gannett and others, 2007). There are also strong upward vertical head gradients adjacent to UKL, particularly to the north in the lower Wood River Valley where there are many flowing artesian wells (Snyder and Morace, 1997). These head gradients, along with the presence of springs on the lake margin, indicate that there is the potential for groundwater seepage to UKL through lakebed sediments.

\section{Background and Previous Work}

Upper Klamath Lake water-quality problems associated with annual algae blooms, combined with numerous and often competing demands for lake water, have motivated a wide range of environmental studies and monitoring in the Upper Klamath basin. An accurate water balance is needed to inform resource management and for scientific understanding of the lake. Several studies have estimated the UKL water balance (Hubbard, 1970; Cooper, 2004; Bureau of Reclamation, 2005; Walker and others, 2012). In these studies, the sum of known and estimated lake outflows and lake storage change was subtracted from the sum of known and estimated lake inflows. A general lake water-balance equation is:

$$
S W_{\text {in }}+G W_{\text {in }}+\text { PRECIP }=S W_{\text {out }}+E T \pm \Delta S,
$$

$$
\begin{aligned}
\text { where } & \\
S W_{\text {in }} & \text { is the inflow of surface water; } \\
G W_{\text {in }} & \text { is the inflow of groundwater; } \\
P R E C I P & \text { is precipitation; } \\
S W_{\text {out }} & \text { is the outflow of surface water; } \\
E T & \text { is evapotranspiration; and } \\
\triangle S & \text { is the change in water stored in the lake. }
\end{aligned}
$$

The groundwater component $\left(G W_{\text {in }}\right)$ in equation 1 represents the combined inflow from springs and direct groundwater seepage through the lake bottom. $G W_{\text {in }}$ is difficult to measure directly. If the other components $\left(S W_{\text {in }}, P R E C I P\right.$, $S W_{\text {out }}, E T$, and $\Delta S$ ) of the water balance are known or estimated, $G W_{\text {in }}$ can be estimated as the residual sum of the other components. There is considerable uncertainty, however, in estimating groundwater inflow using the water-balance residual approach (Walker and others, 2012). The residual value includes the sum of all errors in the estimates of the other water-balance components.

Past estimates of the groundwater component of the UKL water balance have been made using the water-balance residual. Despite the inherent uncertainty of this method, the different studies that have applied it are generally in good agreement. Hubbard (1970) produced a monthly water balance for UKL for water years ${ }^{2} 1965-1967$ and estimated an average monthly groundwater inflow of 350 cubic feet per second $\left(\mathrm{ft}^{3} / \mathrm{s}\right)$, about 15 percent of an average annual lake inflow of $2,330 \mathrm{ft} 3 / \mathrm{s}$ during the period of measurement. Cooper (2004) compared UKL inflows and outflows and the difference between the two compares well with Hubbard's groundwater inflow value (Gannett and others, 2007). The Bureau of

\footnotetext{
$2 \mathrm{~A}$ water year is defined as the 12-month period Beginning October 1, for any given year and continuing through September 30, of the following year.
} 


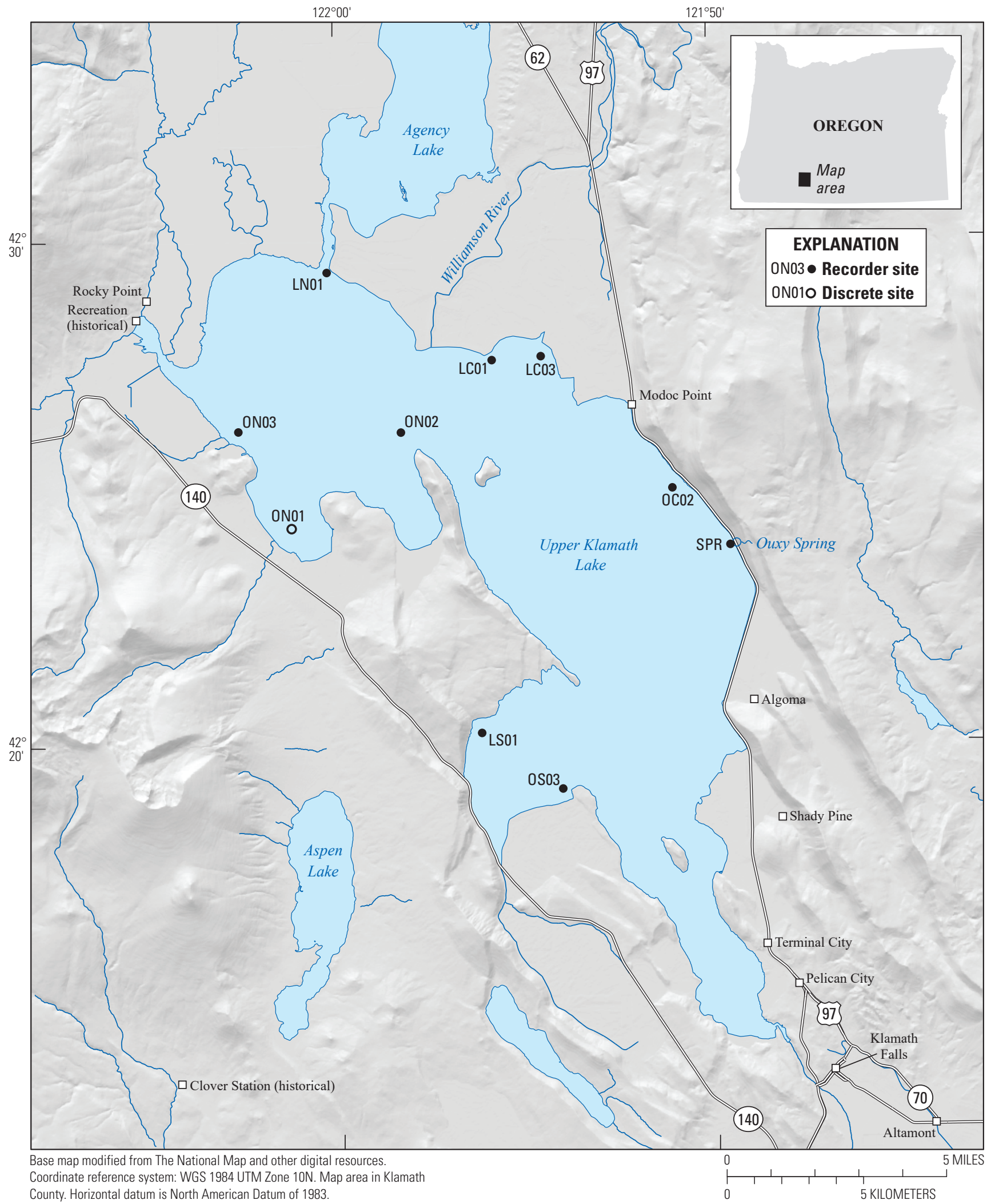

Figure 1. Locations of groundwater piezometer and stilling well paired sets at 10 sites on Upper Klamath Lake, Oregon, 2017. [Continuous data was recovered at nine sites (recorder sites). At ON01, only discrete water-level measurements collected during site visits were available [discrete site]. 
Reclamation (2005) produced a revised groundwater inflow estimate of $320 \mathrm{ft} 3 / \mathrm{s}$ using updated lake stage-volume curves. Walker and others (2012) calculated a water budget for water years 1992-2010 and estimated an average groundwater inflow of approximately $310 \mathrm{ft} 3 / \mathrm{s}$, about 18 percent of an average annual total lake inflow of $1,780 \mathrm{ft}^{3} / \mathrm{s}$ during the period of the study. Although $\mathrm{GW}_{\text {in }}$ represents the combined inflow from springs and direct groundwater seepage, the total measured discharge from springs around the margins of UKL is much less than estimates of $\mathrm{GW}_{\text {in }}$, meaning that an unknown portion of this inflow likely comes from direct groundwater seepage through the lakebed (Gannett and others, 2007).

The flows of water into and out of the lake also transport dissolved and particulate nutrients. Substantial work has been done to study UKL nutrient fluxes (Kann and Walker, 2001; Oregon Department of Environmental Quality, 2002; Walker, 2001; Walker and others, 2012; Wood and others, 2013), but the relative importance of one such flux-nutrient transport by groundwater advection through the lakebed sediment-is not well constrained. Several recent studies have sought to examine this flux by combining nutrient concentration data with estimated rates of biological, diffusive, and advective solute transport across the sediment-water interface. Kuwabara and others $(2009 ; 2012 ; 2016)$ found that nutrient concentrations in UKL lakebed sediment pore-water were often greater than in the overlying lake water. Kuwabara and others $(2009 ; 2016)$ used observed vertical temperature profile data from five locations (one in 2005 and four in 2015) to estimate groundwater flux across the lake-sediment interface using heat-flux modeling. These estimates of groundwater flux varied temporally but were mostly upward (from sediment to lake). Based on these results, Kuwabara and others (2016) suggest that advective transport by groundwater inflow may be an important source of nutrients to the water column of UKL. These studies had large uncertainty because of the lack of reliable vertical head gradient information.

\section{Purpose and Scope}

In 2017, the USGS began studying vertical head gradients beneath UKL, critical to a quantitative understanding of groundwater-lake exchange. Groundwater and lake water levels were measured at 10 sites distributed across UKL during May through October 2017. Water-level data were used to calculate VHG across the sediment-water interface. The calculated VHG values provide new information about the spatial and temporal distribution of exchange in UKL and can be used to define the direction and relative magnitude of groundwaterlake exchange flow at each site.

The scope of this report is (1) a description of the methods used to measure groundwater and lake water levels; (2) a summary of groundwater and lake water-level measurements; (3) a documentation of the calculation of VHG using groundwater and lake water-level measurements; and (4) a summary of VHG data.

\section{Methods and Datasets}

This report describes two datasets collected by the USGS. The first is continuous water-level data from groundwater piezometers and lake stilling wells at specific sites within UKL. The second is discrete field measurements of water levels in groundwater piezometers and lake stilling wells relative to common measurement points (MPs), which were used to verify the accuracy of the continuous water-level data. This report also describes the VHG at each site, which was calculated using the continuous water-level data. The methods and equipment used to collect these data and calculate VHG are described in this section.

\section{Study Design and Sites}

To understand the spatial and temporal distribution of VHG it is necessary to determine the head (water level) in the lake relative to the head in the underlying sediments. Head in the underlying sediments was determined by installing piezometers in the lakebed. The piezometers were open to a discrete interval below the bottom of the lake but were closed to the lake itself. Differences between the water level in the piezometer, which represents the groundwater head, and the lake level, represent the VHG.

Groundwater piezometer and lake stilling well paired sets were deployed at 10 sites (fig. 1) distributed across northern, central, and southern parts of UKL. Equipment was deployed on May 2 and 3, 2017, and was removed on September 27 and October 5,2017. The spring -autumn study period was designed to capture the full extent of the UKL seasonal waterlevel decline and hydraulic conditions before, during, and after the 2017 cyanobacterial bloom.

The 10 locations selected for this study corresponded to sites that have been previously used for other environmental monitoring projects (Kuwabara and others, 2016; StaufferOlsen and others, 2017). The established naming convention for these sites was used in this study for consistency with earlier work. Sites were classified as either littoral (near shore and lake water depth less than $6 \mathrm{ft}$ during spring) or openwater (lake water depth greater than $6 \mathrm{ft}$ during spring) and assigned an "L" or "O," respectively. Based on their position in UKL, sites were then classified into three approximately equal-area geographic sectors: north, central, and south. Sites in each sector were assigned an "N," "C," or "S," respectively. Two-digit serial numbers (starting at 01 and increasing sequentially) were added to the end of each site name to distinguish between sites in the same geographic sector with similar water depths. For example, a littoral site in the northern sector of the lake was named "LN01," a second littoral site in the northern sector was named "LN02," and an open-water site from the southern sector of the lake was named "OS01." One additional site, positioned offshore from Ouxy Spring (on 
the eastern edge of the lake), was named "SPR," as it had been in previous studies. In this report, SPR is considered an openwater site.

Data collection was interrupted several times. The piezometer pipe at LN01 was found damaged on May 31, 2017, and was removed, repaired, and redeployed on June 22, 2017. Due to the limited discrete check measurements available before the damage occurred, only data after redeployment data at LN01 has been published. Piezometers deployed at ON02, SPR, and OC02 were lost within 2 weeks of initial deployment due to wave action, equipment failure, or vandalism. New equipment was redeployed at ON02 and SPR on June 26, 2017, and at OC02 on July 12, 2017. The equipment at ON01 was lost between site visits on August 1 and 15, 2017. Equipment was not redeployed at ON01; therefore, only discrete data collected before August 1, 2017 were available at this site for this report. Complete site and equipment deployment information is presented in table 1.

\section{Piezometers and Stilling Wells}

The feasibility of deploying equipment to continuously monitor shallow groundwater and lake water levels was demonstrated by Kuwabara and others (2016). This study used a paired piezometer and stilling well design like that described by Kuwabara and others (2016), with minor adjustments to allow for periodic field water-level measurements and to improve transducer stability (fig. 2). Groundwater piezometer and lake-level stilling well paired sets deployed at each site were secured together with stainless steel band clamps. The piezometer was constructed with a section of 1-inch (in) diameter galvanized steel pipe, connected by a galvanized steel reducer coupling to a section of 0.75 -in diameter galvanized steel pipe, which was threaded into a Solinst 0.75 -in stainless steel model 615 drive-point piezometer well point with a 12-in long screen. The length of the 1-in diameter pipe was adjusted according to the water depth at each site so that there was $2 \mathrm{ft}$ of pipe above the surface of the water at the time of deployment. Piezometer deployment depth was controlled by a 15.75-in square, 0.4-in thick, polyvinyl chloride (PVC) base plate with a 1-in diameter hole drilled in its center. The base

Table 1. Site locations and deployment durations, Upper Klamath Lake, Oregon, 2017.

[Sites were classified as either littoral (lake water depth less than $6 \mathrm{ft}$ during spring) or open-water (lake water depth greater than $6 \mathrm{ft}$ during spring). Abbreviations: NAD 83, North American Datum of 1983; - , equipment was lost during deployment and not recovered]

\begin{tabular}{|c|c|c|c|c|c|c|c|c|}
\hline Site & $\begin{array}{l}\text { U.S. Geological } \\
\text { Survey site No. }\end{array}$ & Site type & $\begin{array}{l}\text { Habitat } \\
\text { type }\end{array}$ & $\begin{array}{l}\text { Lake } \\
\text { sector }\end{array}$ & $\begin{array}{l}\text { Latitude } \\
\text { (NAD 83) }\end{array}$ & $\begin{array}{l}\text { Longitude } \\
\text { (NAD 83) }\end{array}$ & $\begin{array}{c}\text { Date } \\
\text { equipment } \\
\text { deployed }\end{array}$ & $\begin{array}{l}\text { Date equipment } \\
\text { retrieved }\end{array}$ \\
\hline LN01 & $\begin{array}{l}422922122001301 \\
422922122001300\end{array}$ & $\begin{array}{c}\text { Groundwater } \\
\text { Lake }\end{array}$ & Littoral & North & 42.48951 & -122.00369 & May 2, 2017 & October 5, 2017 \\
\hline ON01 & $\begin{array}{l}422519121531201 \\
422519121531200\end{array}$ & $\begin{array}{c}\text { Groundwater } \\
\text { Lake }\end{array}$ & $\begin{array}{l}\text { Open } \\
\text { water }\end{array}$ & North & 42.40510 & -122.02060 & May 2, 2017 & - \\
\hline ON02 & $\begin{array}{l}422612121581701 \\
422612121581700\end{array}$ & $\begin{array}{c}\text { Groundwater } \\
\text { Lake }\end{array}$ & $\begin{array}{l}\text { Open } \\
\text { water }\end{array}$ & North & 42.43655 & -121.97142 & $\begin{array}{c}\text { June } 26, \\
2017\end{array}$ & October 5, 2017 \\
\hline $\mathrm{LC} 01$ & $\begin{array}{l}422736121555001 \\
422736121555000\end{array}$ & $\begin{array}{c}\text { Groundwater } \\
\text { Lake }\end{array}$ & Littoral & Central & 42.46010 & -121.93056 & $\begin{array}{c}\text { June } 22, \\
2017 \\
\end{array}$ & $\begin{array}{c}\text { September } 27, \\
2017 \\
\end{array}$ \\
\hline SPR & $\begin{array}{l}422354121493101 \\
422354121493100\end{array}$ & $\begin{array}{c}\text { Groundwater } \\
\text { Lake }\end{array}$ & $\begin{array}{l}\text { Open } \\
\text { water }\end{array}$ & Central & 42.39842 & -121.82523 & $\begin{array}{c}\text { June } 26, \\
2017\end{array}$ & October 5, 2017 \\
\hline $\mathrm{OC} 02$ & $\begin{array}{l}422502121510301 \\
422502121510300\end{array}$ & $\begin{array}{c}\text { Groundwater } \\
\text { Lake }\end{array}$ & $\begin{array}{l}\text { Open } \\
\text { water }\end{array}$ & Central & 42.41734 & -121.85075 & $\begin{array}{r}\text { July } 12 \text {, } \\
2017 \\
\end{array}$ & October 5, 2017 \\
\hline OS03 & $\begin{array}{l}421906121540401 \\
421906121540400\end{array}$ & $\begin{array}{c}\text { Groundwater } \\
\text { Lake }\end{array}$ & $\begin{array}{l}\text { Open } \\
\text { water }\end{array}$ & South & 42.31841 & -121.90110 & May 3, 2017 & October 5, 2017 \\
\hline LS01 & $\begin{array}{l}422014121561301 \\
422014121561300\end{array}$ & $\begin{array}{c}\text { Groundwater } \\
\text { Lake }\end{array}$ & Littoral & South & 42.33709 & -121.93687 & May 3, 2017 & October 5, 2017 \\
\hline
\end{tabular}


plate was slid onto and clamped to the 1 -in diameter steel pipe $4.92 \mathrm{ft}$ above the bottom of the piezometer screen. During deployment, the piezometers were manually driven into the lakebed sediment off the side of a boat. The base plates rested on the lakebed, providing stability to the equipment, and controlling the depth to which the piezometer screens extended into the lakebed sediment. Piezometer screens were set at 3.92 through $4.92 \mathrm{ft}$ below the lakebed at all locations. This depth interval was selected for consistency with earlier studies that used lakebed sediment temperature data over the interval 4.92 $\mathrm{ft}$ below the lakebed to model groundwater fluxes (Kuwabara and others, 2009; Kuwabara and others, 2016). Immediately following deployment, about 5 liters (L) of water were rapidly added to the piezometers to flush fines away from the piezometer screen and thereby improve the hydrologic connection with the lakebed sediment.

The lake-level stilling wells were constructed out of 2-in diameter schedule 40 PVC. The wells were designed to have $2 \mathrm{ft}$ of pipe above the lake surface at the time of deployment in May and at least $2 \mathrm{ft}$ of pipe below the lake surface at low stage in October. To meet these design requirements, and to accommodate a conservatively estimated $6 \mathrm{ft}$ of lake-level drop between equipment deployment and removal, 10-ft-long stilling well pipes were used. A perforated 2-in PVC end cap was attached to the bottom of the stilling well for hydrologic connection to the lake. The perforated cap was screened with copper mesh to reduce biofouling on transducers installed within the stilling well pipe.

Recording pressure transducers were deployed inside all piezometers and stilling wells. Transducers were hung on vinyl-coated stainless-steel wires attached to stainless-steel locking pins. The pins were installed horizontally through holes drilled into the piezometer and stilling well casings (fig. 2). The top 3-ft sections of the piezometer and stilling well pipe were designed to be removed mid-deployment so that, as lake elevation dropped, increasing amounts of pipe above the lake surface would not prevent the collection of depth to water measurements by boat. Removal of the upper sections would also prevent the piezometer apparatus from becoming top-heavy and unstable. The top sections of the piezometers and stilling wells were removed on August 25th and 30th, 2017. The pressure transducers were briefly removed from the wells during this process and were replaced on shortened wires once the pipe adjustment was completed.

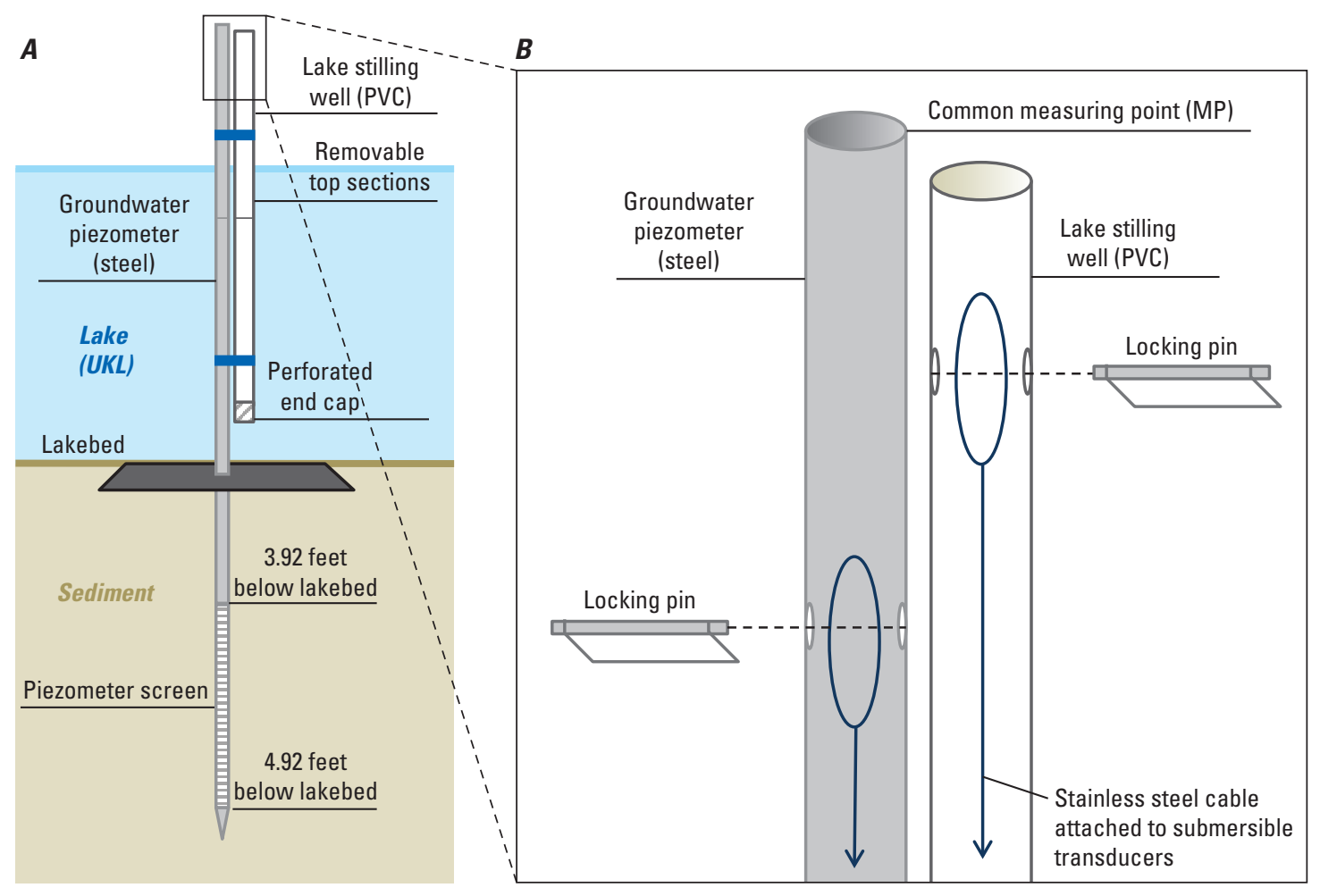

Figure 2. (A) Schematic diagram of the groundwater piezometer and lake stilling well apparatus deployed at 10 locations and $(B)$ detail view of the recording pressure transducer configuration with the common measuring point for groundwater and lake depth-to-water measurements, Upper Klamath Lake, 2017. [The groundwater piezometer screen was open to the lakebed sediment from 3.92 to 4.92 feet below the lakebed surface. The stilling well was open to the lake. Schematic diagram is not to scale. Schematic detail view is not to scale. PVC, polyvinyl chloride] 


\section{Continuous Water-Level Data}

Piezometers and stilling wells were instrumented with Solinst Edge Model 3001 Levelogger unvented pressure transducers. The transducers recorded sensor depth at 10-minute intervals. Barometric pressure was recorded at the Rocky Point lake gage (USGS site 11505800 [Upper Klamath Lake at Rocky Point, OR]) with a Solinst 3001 Barologger, which was set to record at the same interval as the water-level transducers (fig. 3). The continuous water-level data was corrected for barometric pressure by subtracting the barometric pressure reading from the sensor-depth reading. The corrected sensordepth readings were converted to values of depth below MP using the field-measured depth to water value collected at the time of sensor deployment.

Some drift was observed during portions of the continuous data record likely caused by changes in well and logger position from the effects of waves and wind. Drift offset corrections were applied to the continuous water-level data to ensure good agreement $( \pm 0.02 \mathrm{ft})$ with periodic field-measured water levels. The magnitudes of the corrections were commonly $0.01-0.03 \mathrm{ft}$. An offset correction was applied to the time-series data after the top-section removal to account for any change in sensor position within the well. Spikes in the water-level time-series data associated with site visits were also removed from the continuous record. Portions of the continuous water-level data from four groundwater pressure transducers (LN01, ON02, ON03, LC01) could not be reasonably corrected to match field verification measurements. These data were removed from the continuous record. In all instances, these periods of unusable data began after several months of reliable data had been collected. It is possible that the systematic deviations in the raw transducer readings were the result of low battery or sensor fouling. Discrete field waterlevel measurements have been reported where continuous data from one sensor was unusable.

\section{Discrete Water-Level Data}

Water levels were measured from a boat during site visits at approximately 2 -week intervals using a calibrated electric water-level tape (Waterline, $150 \mathrm{ft}$ Coax Water Level Meter). These measurements were used to verify the accuracy of the transducer readings and, if necessary, to correct the continuous water-level data. At each site, water levels were measured in the piezometer and stilling well relative to a common MP (fig. 2). MPs were marked on the top of the galvanized pipe at each paired set. Repeat measurements were collected to confirm original readings according to the methods of Cunningham and Schalk (2011). MPs were not surveyed to a vertical datum due to the distance of the wells from shore and the prohibitive difficulty of surveying well elevations from a boat. For calculating VHG at each location, water-level measurements relative to a common datum (in this case, a common MP) were considered sufficient. To minimize measurement error, discrete water-level measurements were not collected when there was strong wind or wave action. The water-level tape used to collect field measurements was calibrated by the USGS Hydrologic Instrumentation Facility. Tape calibration adjustments (equal to $-0.01 \mathrm{ft}$ for all measurements) were applied to raw field-collected water-level measurements.

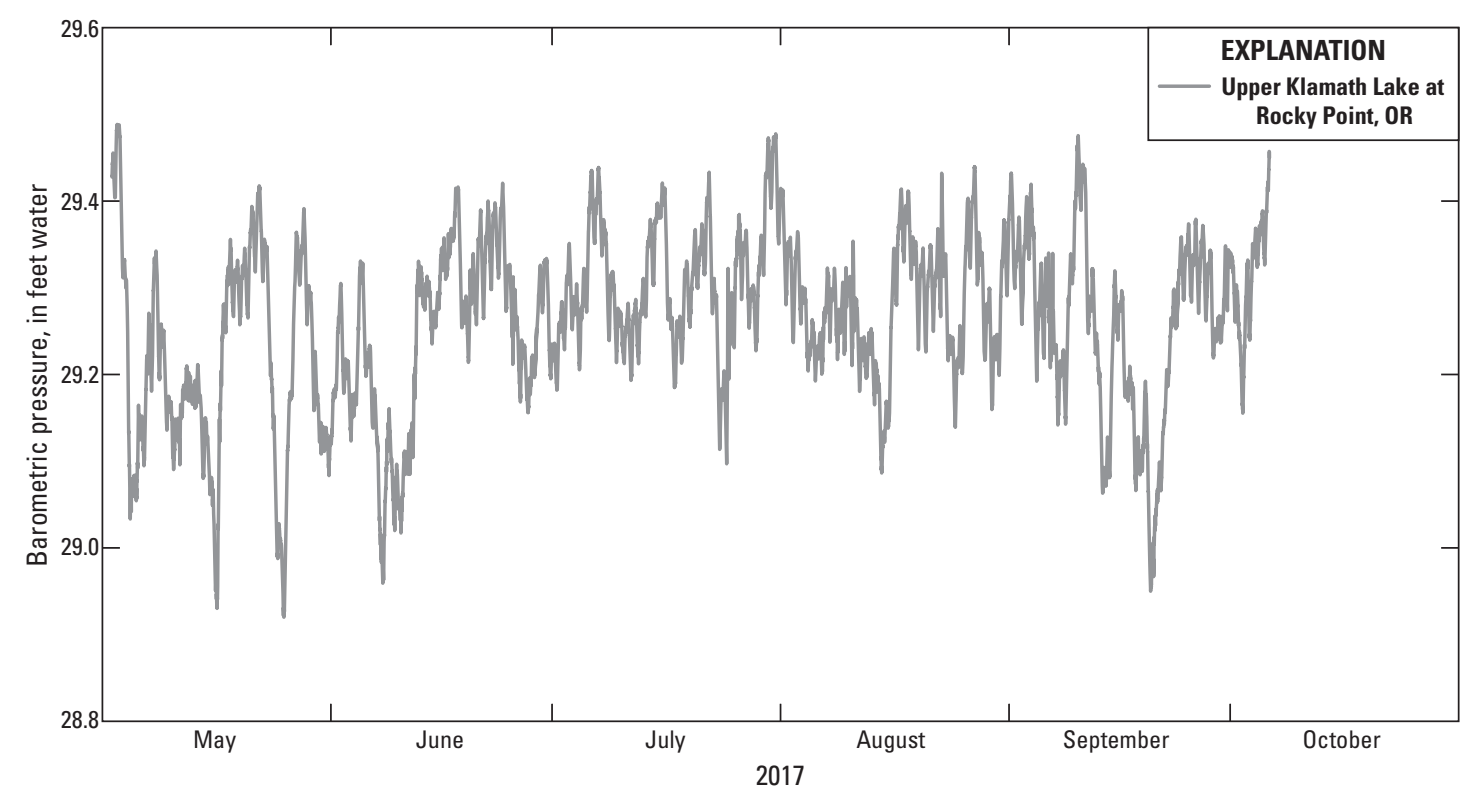

Figure 3. Barometric pressure at the Rocky Point gage, Upper Klamath Lake, Oregon, 2017. [U.S. Geological Survey site number 11505800 (Upper Klamath Lake at Rocky Point, OR)] 


\section{Vertical Hydraulic Gradient}

Vertical hydraulic gradient was calculated by dividing the difference between the depth to water in the groundwater piezometer and the depth to water in the lake stilling well (equal to the difference in hydraulic head across the sedimentwater interface) by the vertical distance between the midpoint of the piezometer screen and the lakebed (equation 2).

$$
\frac{\left(D T W_{g w}-D T W_{\text {lake }}\right)}{l}=\mathrm{VHG}
$$

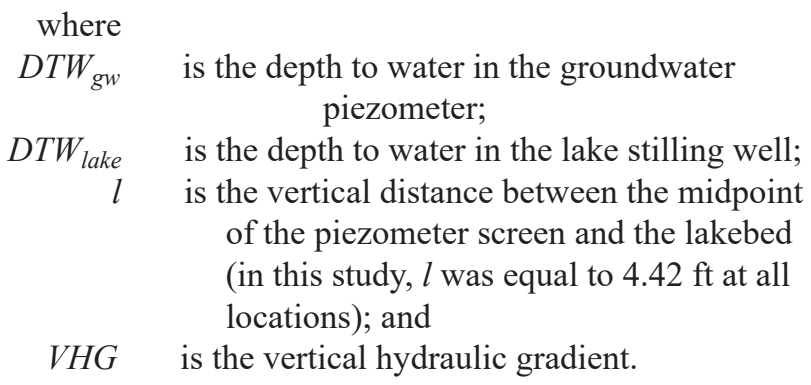

$V H G$ was calculated at each location where reliable data were simultaneously available for both the piezometer and the stilling well. Positive values of VHG indicate conditions for upward flow (flow from the sediment into the lake), negative values of VHG indicate conditions for downward flow (flow from lake into the sediment), and VHG values equal to zero indicate the absence of conditions for advective water exchange between the lake and the sediment. The VHG value does not quantify the amount of flow but provides information about the direction and relative magnitude of flow at each location, assuming no change in vertical lakebed hydraulic conductivity over the study period.

\section{Uncertainty}

The uncertainty in each water-level measurement was conservatively assumed to be $\pm 0.02 \mathrm{ft}$, equal to twice the measurement accuracy of the electric tape used for field water-level verification measurements and the uncertainty of the recording pressure transducers $( \pm 0.01 \mathrm{ft})$. Substituting the combined uncertainty of the groundwater $\left(D T W_{\mathrm{gw}}\right)$ and lake water-level $\left(D T W_{\text {lake }}\right)$ measurements $( \pm 0.04 \mathrm{ft})$ and the length depth to the midpoint of the screen $(4.42 \mathrm{ft})$ in equation 2 yield a VHG uncertainty of $\pm 0.009 \mathrm{ft} / \mathrm{ft}$. Therefore, VHG values between $-0.009 \mathrm{ft} / \mathrm{ft}$ and $0.009 \mathrm{ft} / \mathrm{ft}$ were within the measurement accuracy of the equipment used in this study and cannot be confidently determined to be either upward or downward. This large band of uncertainty was necessary owing to the challenges associated with measuring small head differences in a wave-impacted lake system experiencing weather-induced barometric pressure fluctuations.

\section{Data Summary}

Water-level and calculated VHG data from the 10 study sites are presented (figs. 3-13) and summarized (table 2) in this section. The amount of data available at each site within this period varied depending on the length of equipment deployment and transducer performance. Corson-Dosch (2020) has complete records of collected continuous waterlevel data, discrete water-level data, and VHG.

\section{Water Levels}

Lake water levels at all sites steadily declined during the study period. Spring to autumn lake level decline occurs annually in UKL and can be attributed to decreased precipitation, irrigation withdrawals (both directly from UKL and from tributary rivers), the release of water from the Link River Dam downstream to the Klamath River, and increased evapotranspiration- the rates of which are highest during summer (Stannard and others, 2013). Groundwater levels in lake-bed piezometers also declined over this period and closely tracked lake levels. Generally, only small differences were observed between lake and sub-lake groundwater levels, averaging 0.03 $\mathrm{ft}$ over the study period.

In addition to the observed seasonal decline in water levels, there were frequent but small (approximately $0.1 \mathrm{ft}$ ) fluctuations in both lake and sub-lake groundwater levels that occurred at frequencies of less than 1 day to less than 1 hour. These fluctuations were probably caused by wave action or small seiche events driven by prevailing north to northwest winds. Wind and waves such as these were frequently observed. There were also less frequent, large fluctuations (approximately $0.25 \mathrm{ft}$ and greater) in the continuous lake water-level data. These larger fluctuation events could typically be observed at all sites (for example, large fluctuations that occurred on July 25th and August 10th). Because these fluctuation events occurred simultaneously at sites across the lake, it is unlikely that they are anomalies related to data collection. They were probably caused by higher-intensity winds or storm events. The larger fluctuation events can also be observed in the continuous groundwater-level data all sites, though groundwater-level fluctuations generally had smaller amplitude than lake-level fluctuations.

Post-deployment continuous water-level records from three of the nine piezometers showed recovery curves following the $5 \mathrm{~L}$ water slug added for piezometer development immediately after deployment. At LC03 and, to a much smaller extent, OC02, post-deployment water levels showed slow, decreasing recovery curves from the time-ofdeployment slug to local groundwater conditions. Following the time-of-deployment slug, LC03 decreased $2.70 \mathrm{ft}$ over 4.5 days and OC02 decreased $0.28 \mathrm{ft}$ over 3.5 days. Postdeployment groundwater levels at ON03 also show a slow recovery to local conditions but, unlike $\mathrm{LC} 03$ and $\mathrm{OC} 02$, water levels at ON03 increased to local conditions following 
Table 2. Continuous data collection and mean vertical hydraulic gradient (VHG) during each week and during the study period at each site, Upper Klamath Lake, Oregon, 2017.

[Available 10-minute VHG data from each week-long period were used to calculate weekly mean values. The bold, colored values exceeded measurement uncertainty ( \pm 0.009 foot per foot). The colors indicate gradient direction: positive upward values are blue and negative downward values are red. The colorless values were within measurement accuracy and could not be confidently determined to be either upward or downward. No continuous data were recovered from ON01. Site locations can be seen in figure 1. Abbreviations: VHG, vertical hydraulic gradient; ft/ft, foot per foot; -, no data available]

\begin{tabular}{|c|c|c|c|c|c|c|c|c|c|}
\hline \multirow{2}{*}{$\begin{array}{l}\text { Measurement } \\
\text { period }\end{array}$} & \multicolumn{9}{|c|}{ Weekly mean VHG (ft/ft; unitless) } \\
\hline & SPR & OS03 & ON02 & ON03 & 0C02 & LCO3 & LS01 & LCO1 & LN01 \\
\hline May $2-7,2017$ & - & 0.0014 & - & $-0.0490^{1}$ & - & $0.1768^{2}$ & 0.0204 & - & 0.0067 \\
\hline May 8-14, 2017 & - & -0.0003 & - & -0.0090 & - & 0.0146 & 0.0245 & - & 0.0011 \\
\hline May 15-21, 2017 & - & 0.0019 & - & 0.0022 & - & 0.0102 & 0.0199 & - & -0.0018 \\
\hline May 22-28, 2017 & - & 0.0029 & - & 0.0068 & - & 0.0106 & 0.0189 & - & 0.0080 \\
\hline $\begin{array}{l}\text { May 29-June 4, } \\
2017\end{array}$ & - & 0.0008 & - & -0.0086 & - & 0.0112 & 0.0186 & - & 0.0072 \\
\hline June 5-11, 2017 & - & 0.0020 & - & -0.0144 & - & 0.0111 & 0.0179 & - & 0.0047 \\
\hline June 12-18, 2017 & - & 0.0016 & - & -0.0130 & - & 0.0086 & 0.0195 & - & 0.0043 \\
\hline June 19-25, 2017 & - & -0.0007 & - & -0.0036 & - & 0.0108 & 0.0173 & - & 0.0040 \\
\hline $\begin{array}{l}\text { June 26-July 2, } \\
\quad 2017\end{array}$ & -0.013 & -0.0002 & -0.0019 & 0.0037 & - & 0.0117 & 0.0113 & - & 0.0013 \\
\hline July 3-9, 2017 & -0.009 & 0.0019 & 0.0032 & 0.0092 & - & 0.0121 & 0.0129 & 0.0033 & -0.0017 \\
\hline July 10-16, 2017 & -0.017 & 0.0023 & 0.0019 & - & - & 0.0108 & 0.0128 & 0.0028 & 0.0090 \\
\hline July 17-23, 2017 & -0.028 & 0.0018 & -0.0041 & - & 0.0077 & 0.0105 & 0.0131 & 0.0041 & - \\
\hline July 24-30, 2017 & 0.0011 & 0.0002 & -0.0016 & - & -0.0063 & 0.0101 & 0.0114 & 0.0034 & - \\
\hline $\begin{array}{l}\text { July } 31 \text {-August } 6 \text {, } \\
2017\end{array}$ & 0.0017 & 0.0013 & 0.0022 & - & -0.0111 & 0.0099 & 0.0099 & 0.0019 & - \\
\hline $\begin{array}{l}\text { August 7-13, } \\
2017\end{array}$ & -0.0012 & -0.0013 & 0.0047 & - & -0.0159 & 0.0106 & 0.0067 & 0.0006 & - \\
\hline $\begin{array}{l}\text { August 14-20, } \\
2017\end{array}$ & -0.0035 & -0.0014 & 0.0052 & - & -0.0084 & 0.0109 & 0.0081 & -0.0001 & - \\
\hline $\begin{array}{l}\text { August 21-27, } \\
2017\end{array}$ & -0.0054 & -0.0008 & -0.0015 & - & 0.0012 & 0.0109 & 0.0074 & -0.0007 & - \\
\hline $\begin{array}{l}\text { August 28- } \\
\text { September 3, } \\
2017\end{array}$ & -0.0015 & -0.0016 & - & - & 0.0079 & 0.0117 & 0.0039 & 0.0106 & - \\
\hline $\begin{array}{l}\text { September 4-10, } \\
\quad 2017\end{array}$ & 0.0008 & -0.0038 & - & - & 0.0091 & 0.0108 & 0.0007 & 0.0052 & - \\
\hline $\begin{array}{l}\text { September 11-17, } \\
2017\end{array}$ & 0.0074 & -0.0039 & - & - & 0.0090 & 0.0085 & -0.0006 & 0.0061 & - \\
\hline $\begin{array}{l}\text { September 18-24, } \\
2017\end{array}$ & -0.0103 & -0.0050 & - & - & 0.0090 & 0.0049 & -0.0037 & - & - \\
\hline $\begin{array}{l}\text { September 25- } \\
\text { October 1, } \\
2017\end{array}$ & -0.0005 & -0.0048 & - & - & 0.0076 & 0.0046 & -0.0047 & - & - \\
\hline $\begin{array}{l}\text { October 2-5, } \\
20173\end{array}$ & 0.0006 & -0.0061 & - & - & 0.0074 & - & -0.0089 & - & - \\
\hline $\begin{array}{c}\text { Study period } \\
\text { mean VHG }\end{array}$ & -0.0052 & -0.0005 & 0.0009 & -0.0030 & 0.0014 & 0.0102 & 0.0103 & 0.0034 & 0.0039 \\
\hline
\end{tabular}

${ }^{1}$ Mean VHG value likely influenced by slow recovery of piezometer water levels after installation and is not representative of equilibrium conditions over this period. ONO3 study period mean VHG does not include this value.

${ }^{2}$ Mean VHG value likely influenced by slow recovery of piezometer water levels following screen development slug and is not representative of equilibrium conditions over this period. LC03 study period mean VHG does not include this value.

3All equipment removed by October 5, 2017, less than 1 week after measurement began. 
the time-of-deployment slug test, increasing $0.72 \mathrm{ft}$ over 1.5 days. It is possible that ON03 was not filled with water during the post-deployment piezometer slug and slowly filled with groundwater thereafter. Continuous water level records from the other six piezometers that had continuous water-level data did not show discernable recovery from the post-deployment piezometer slug. Because the same installation procedures were used to deploy all piezometers, the variation in water level recovery time observed among these nine sites indicates probable spatial heterogeneity in lakebed sediment hydraulic conductivity.

\section{Vertical Hydraulic Gradient}

Instantaneous VHG estimates, derived from water levels measured at 10-minute intervals, exhibited temporal fluctuations. At all sites, instantaneous VHG values were commonly within the range of measurement uncertainty $( \pm 0.009 \mathrm{ft} / \mathrm{ft})$ but frequently exceeded that range. 63 percent of instantaneous measurements were within this range. Instantaneous VHG values exceeding the range of uncertainty also changed in magnitude with high frequency and often changed direction from upward to downward (or downward to upward) on time scales ranging from less than 1 day to less than 1 hour. These frequent changes in VHG indicate that the rate and direction of lake-groundwater exchange at the sediment-water interface are dynamic. It is likely that the hourly to daily variability in VHG observed across UKL is driven by short-term and often rapid changes in lake water level due to wave action or seiches. Other studies that have measured exchange flow across the sediment-water interface in lakes have documented similar high-frequency variability and observed the influence of waves and seiches (Schneider and others, 2005; Rosenberry and others, 2013; Naranjo and others, 2019). Rosenberry and others (2013) collected high-frequency seepage and VHG measurements at several lakes. They found that seepage rates exhibited substantial temporal variability and responded to changes in surface-water stage within minutes, and they hypothesized seepage rates would be larger during storms. Schneider and others (2005) measured groundwater seepage through lakebed sediment near the shoreline of Oneida Lake in New York and observed considerable variability in seepage rates when wave action was severe. Abrupt changes in lake water level from wave action or seiche events upset the sediment-lake hydraulic equilibrium, inducing instantaneous changes in the direction and magnitude of VHG and, therefore, exchange flow and enhanced mixing across the lakebed interface.
Mean study period VHG was within measurement uncertainty at seven of the nine sites with continuous water-level data, but two near-shore littoral sites $(0.0102 \mathrm{ft} / \mathrm{ft}$ at LC03 and $0.0103 \mathrm{ft} / \mathrm{ft}$ at LS01) had positive (upward) mean study period VHG greater than measurement uncertainty. These sites are likely locations of lakebed groundwater seepage.

Instantaneous VHG values were used to calculate mean VHG over each week of the study period for which data were available (table 2 ). These weekly mean values provide information about the magnitude and variability of site VHG over longer (seasonal and weekly) time scales. Overall, 66 percent of weekly mean VHG values were within the range of measurement uncertainty. At the five deeper open-water sites (including SPR), 80 percent of the weekly mean VHG values (table 2) were within this range, including all weekly mean VHG values at OS03 and ON02. 33 percent of weekly mean VHG values at SPR, 40 percent at ON03, and 25 percent at $\mathrm{OC} 02$ exceeded the range of measurement uncertaintypositive (upward) gradients (VHG greater than $0.009 \mathrm{ft} / \mathrm{ft}$ ) were observed at $\mathrm{ON} 03$ and $\mathrm{OC} 02$, and negative (downward) gradients (VHG less than $-0.009 \mathrm{ft} / \mathrm{ft}$ ) were observed at SPR, ON03, and OC02-but most values at these sites were within measurement uncertainty. Overall, weekly mean VHG values at open-water were variable in both direction and magnitude, indicating the occurrence of intermittent hydraulic exchange in both directions at these sites over the study period.

Weekly mean VHG values at the four near-shore littoral sites were somewhat more consistent in direction and magnitude than those at open-water sites. It is possible that this is because the effects of waves and wind were less at the shallower, near-shore littoral sites. All weekly mean VHG values at littoral sites that exceeded measurement uncertainty were positive (upward flow). Weekly mean VHG values mostly exceeded measurement uncertainty at LC03 (82 percent of values exceeded range of uncertainty) and LS01 (61 percent exceeded) and were predominantly positive (upward flow), although weekly mean VHG values at these sites decreased in magnitude later in the study period. Values were within measurement uncertainty in September at LC03 and in September and October at LS01. Weekly mean VHG values were mostly within measurement uncertainty at LN01 (9 percent exceeded) and LC01 (9 percent exceeded), but each had one positive (upward) value of weekly mean VHG that exceeded measurement uncertainty. Overall, littoral VHG data indicate conditions favorable for consistent groundwater seepage to the lake at LC03 and LS01, particularly in the early part of the study period, and intermittent minor groundwater seepage at LC01 and LN01. 

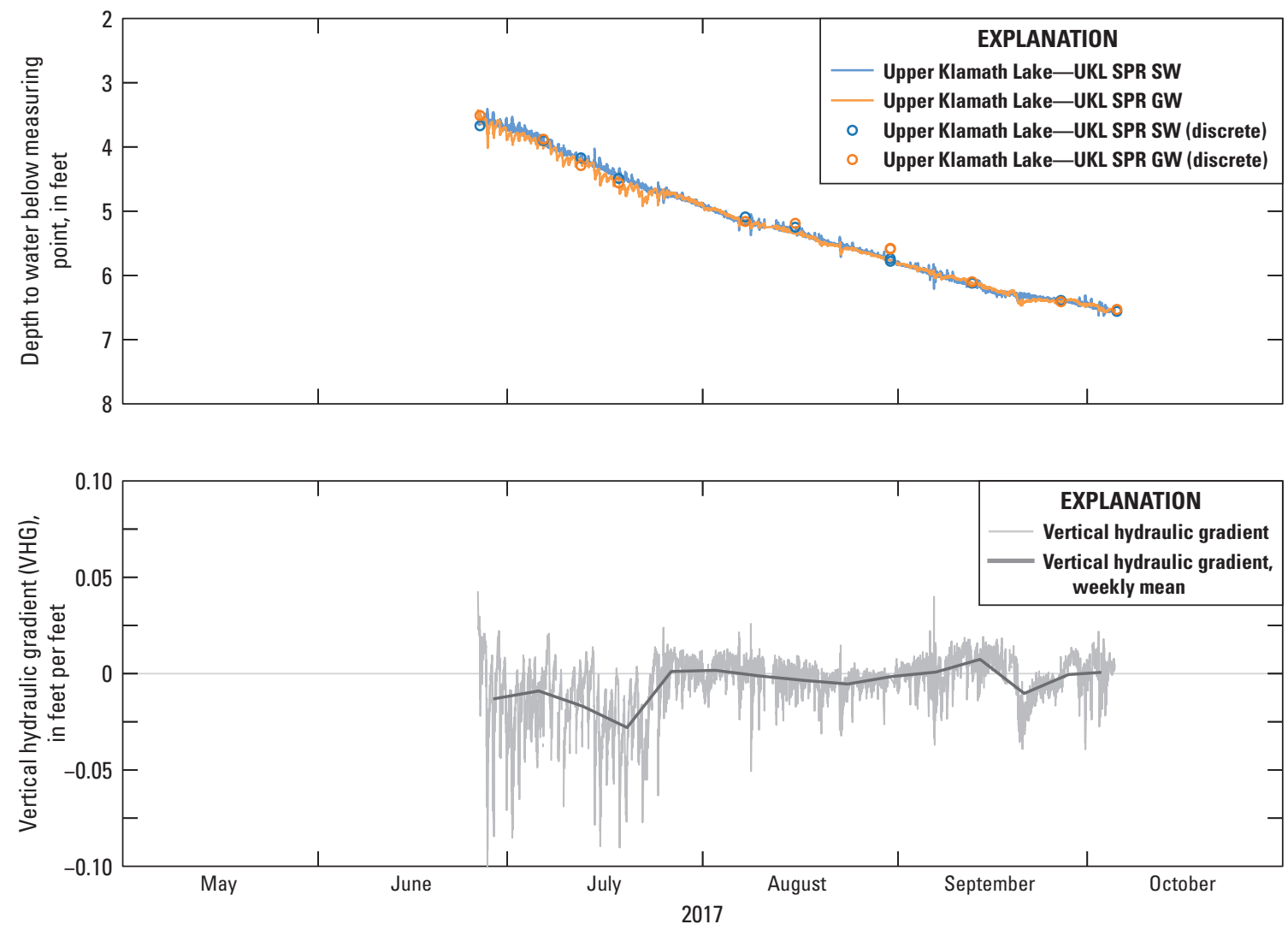

Figure 4. Groundwater and lake depth to water below the measuring point and vertical hydraulic gradient (VHG) at site SPR in Upper Klamath Lake, Oregon, 2017. [Positive values of VHG indicate upward exchange (sediment to lake) and negative values indicate downward exchange (lake to sediment). Site location shown in figure 1] 

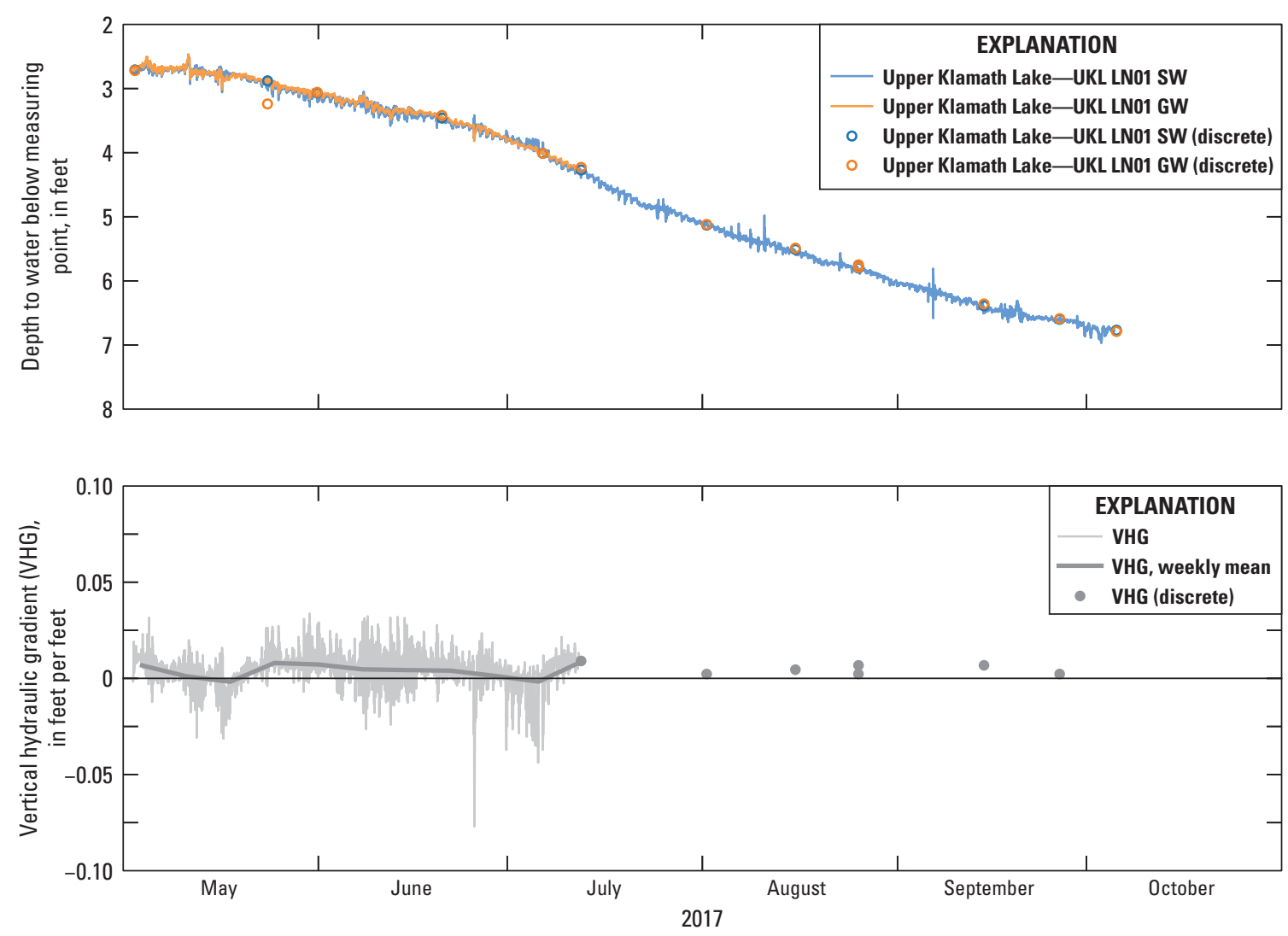

Figure 5. Groundwater and lake depth to water below the measuring point and vertical hydraulic gradient at site LN01 in Upper Klamath Lake, Oregon, 2017. [Positive values of VHG indicate upward exchange (sediment to lake) and negative values indicate downward exchange (lake to sediment). Site location shown in figure 1] 

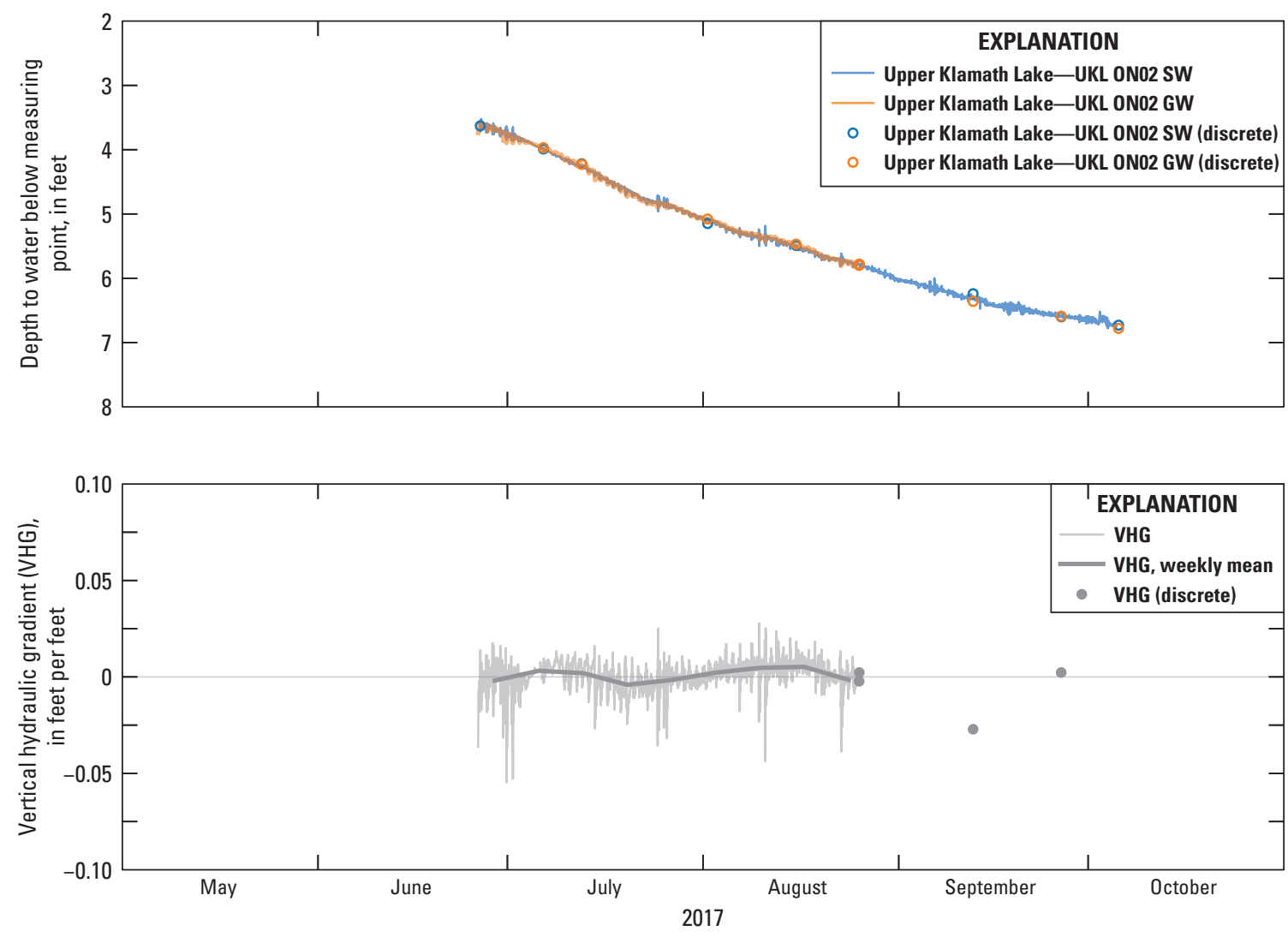

Figure 6. Groundwater and lake depth to water below measuring the point and vertical hydraulic gradient (VHG) at site ON02 in Upper Klamath Lake, Oregon, 2017. [Positive values of VHG indicate upward exchange (sediment to lake) and negative values indicate downward exchange (lake to sediment). Discrete measurements of water level and the VHG values calculated using these measurements are identified in the figure explanation. Site location shown in figure 1] 

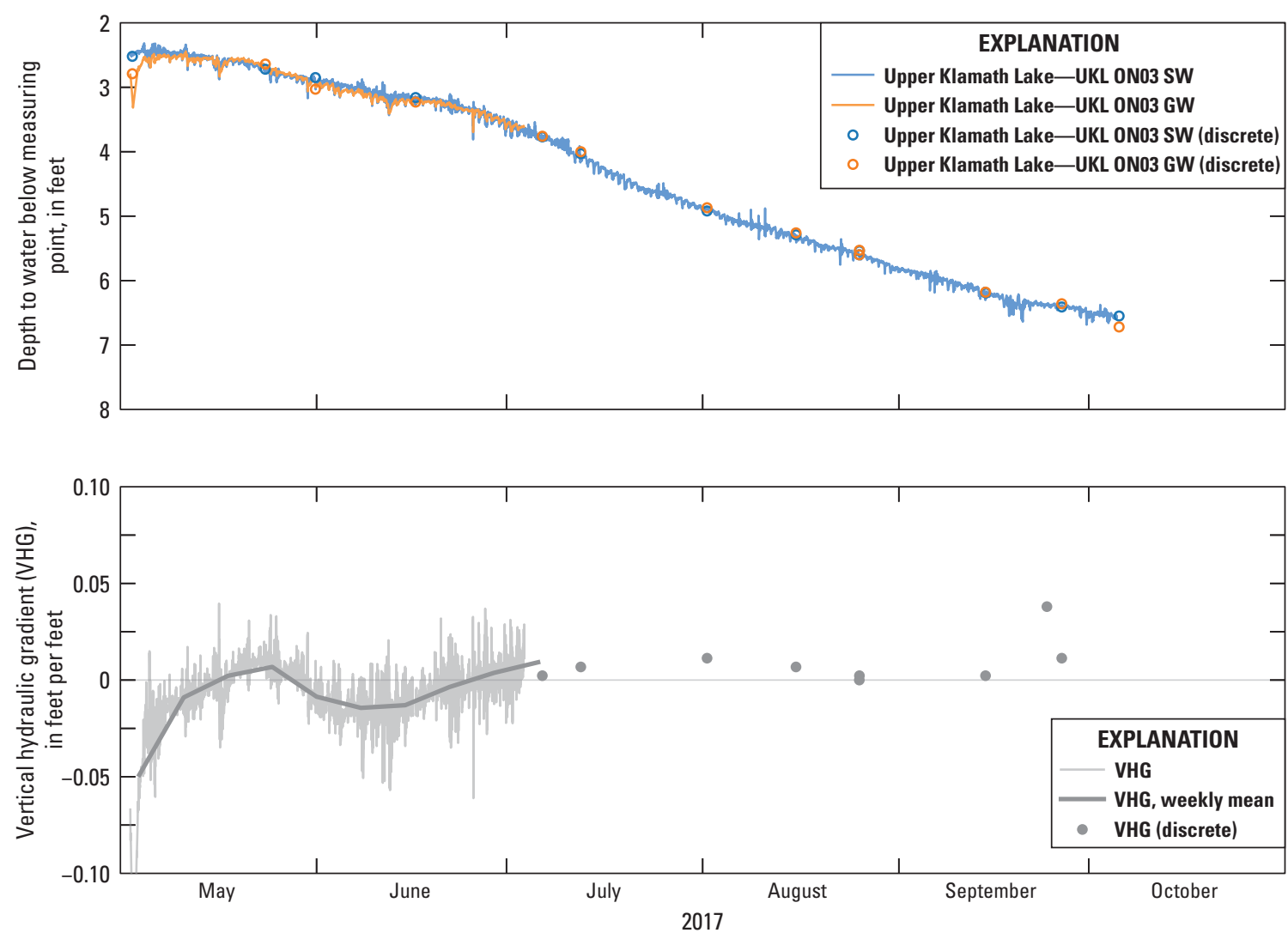

Figure 7. Groundwater and lake depth to water below the measuring point and vertical hydraulic gradient (VHG) at site ON03 in Upper Klamath Lake, Oregon, 2017. [Positive values of VHG indicate upward exchange (sediment to lake) and negative values indicate downward exchange (lake to sediment). Discrete measurements of water level and the VHG values calculated using these measurements are identified in the figure explanation. Site location shown in figure 1] 

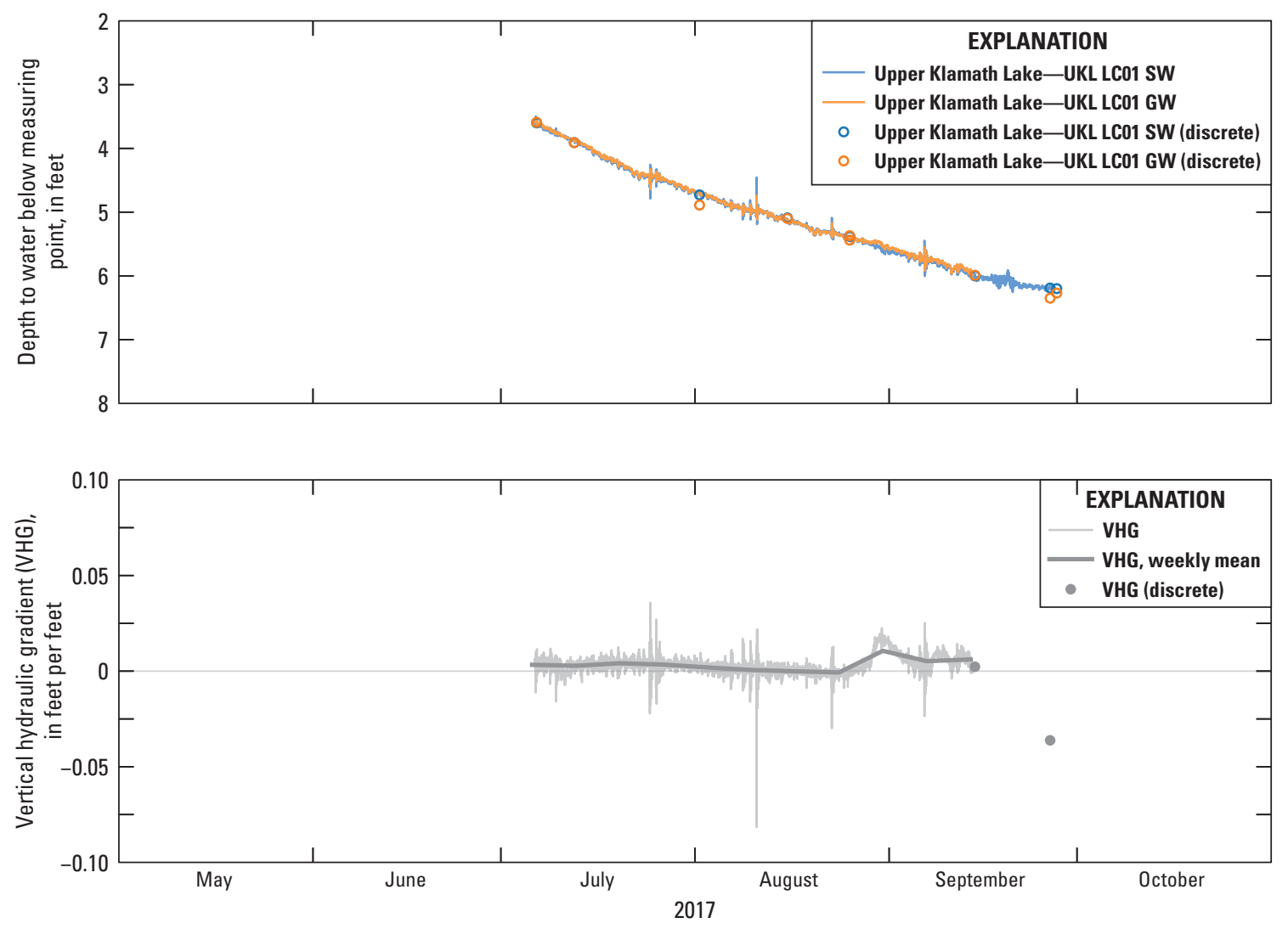

Figure 8. Groundwater and lake depth to water below the measuring point and vertical hydraulic gradient (VHG) at site LCO1 in Upper Klamath Lake, Oregon, 2017. [Positive values of VHG indicate upward exchange (sediment to lake) and negative values indicate downward exchange (lake to sediment). Discrete measurements of water level and the VHG values calculated using these measurements are identified in the figure explanation. Site location shown in figure 1] 

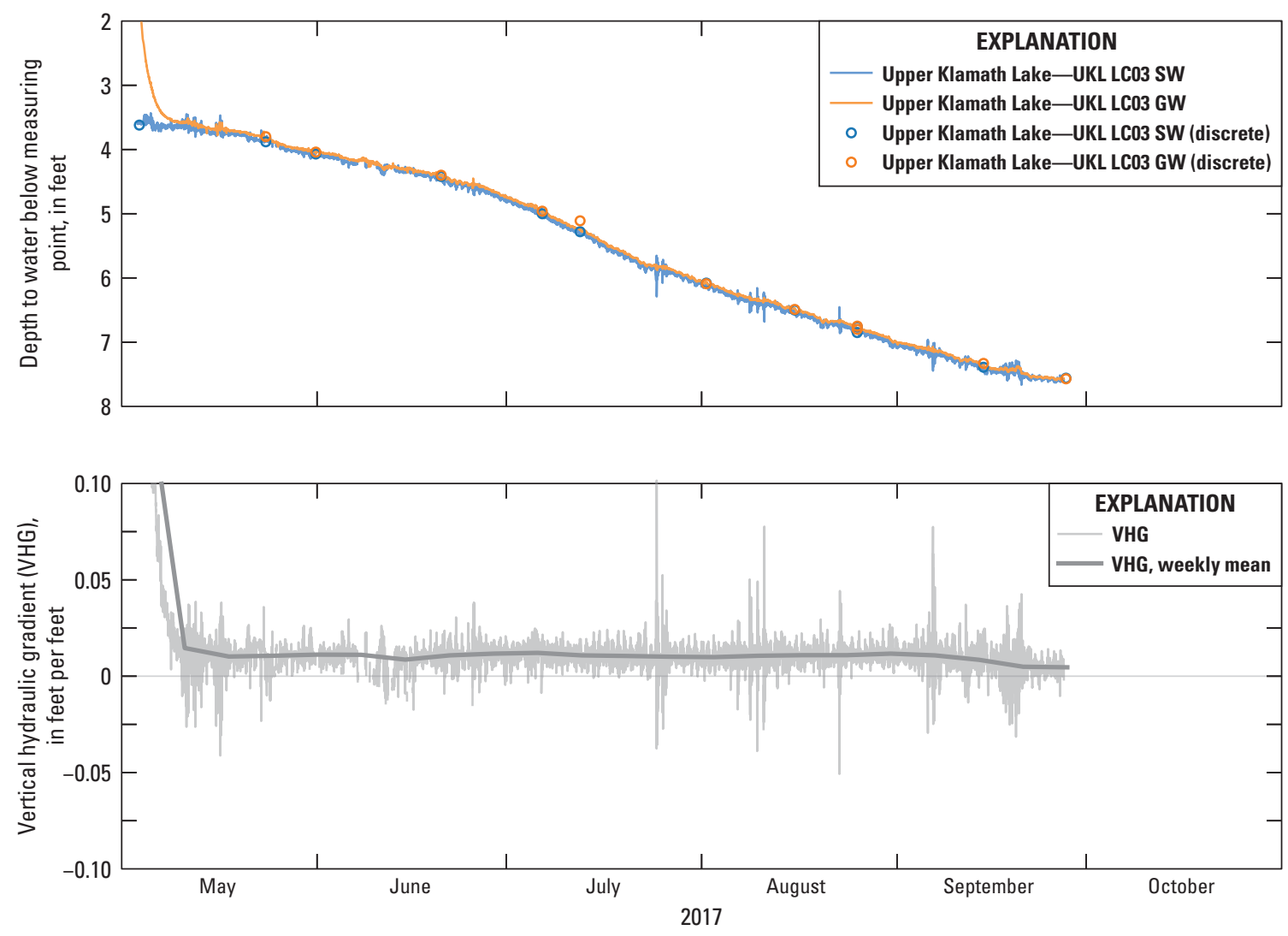

Figure 9. Measured groundwater and lake depth to water below the measuring point and vertical hydraulic gradient (VHG) at site LCO3 in Upper Klamath Lake, Oregon, 2017. [Positive values of VHG indicate upward exchange (sediment to lake) and negative values indicate downward exchange (lake to sediment). Site location shown in figure 1] 

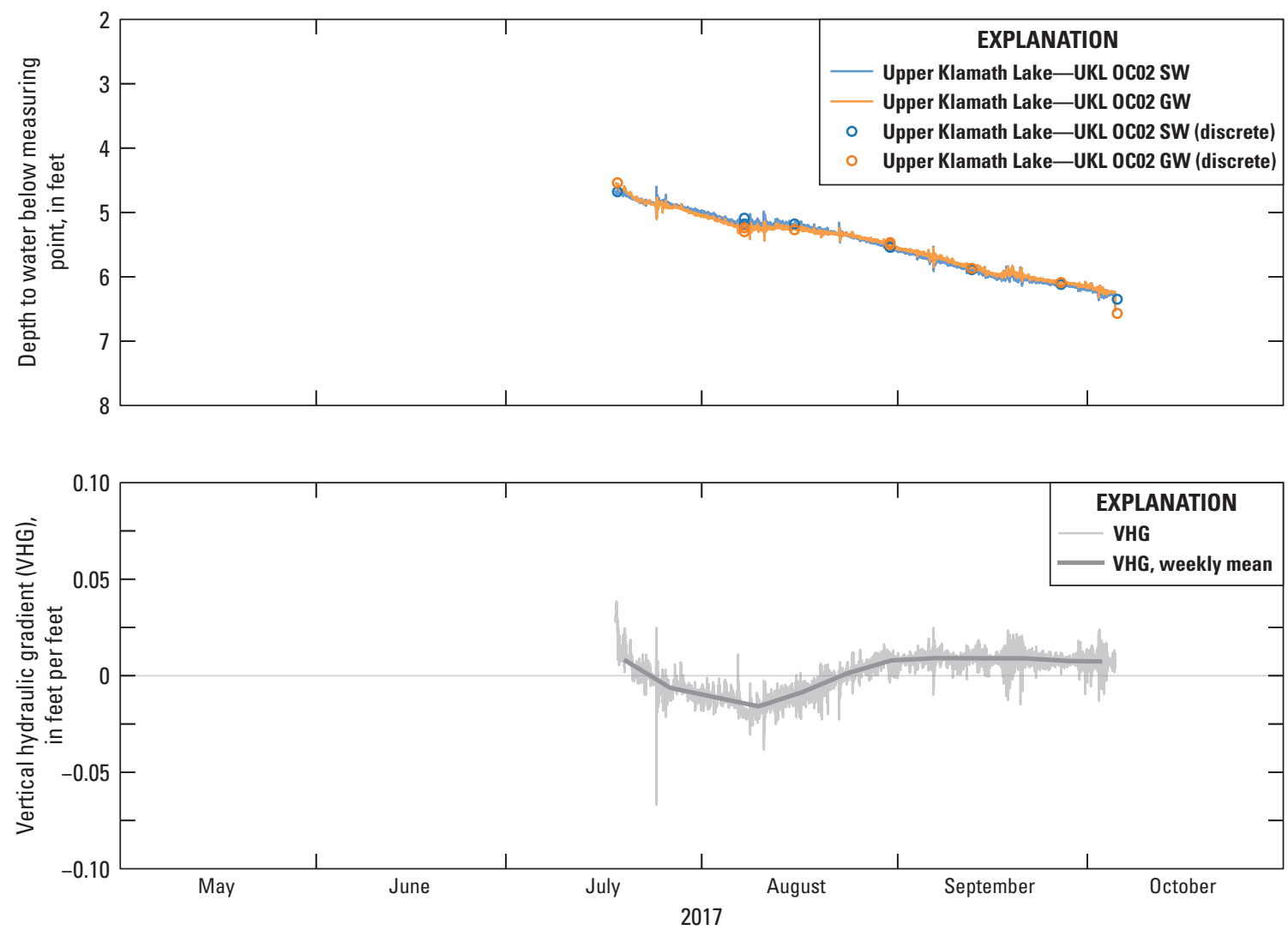

Figure 10. Groundwater and lake depth to water below the measuring point and vertical hydraulic gradient (VHG) at site OCO2 in Upper Klamath Lake, Oregon, 2017. [Positive values of VHG indicate upward exchange (sediment to lake) and negative values indicate downward exchange (lake to sediment). Site location shown in figure 1] 

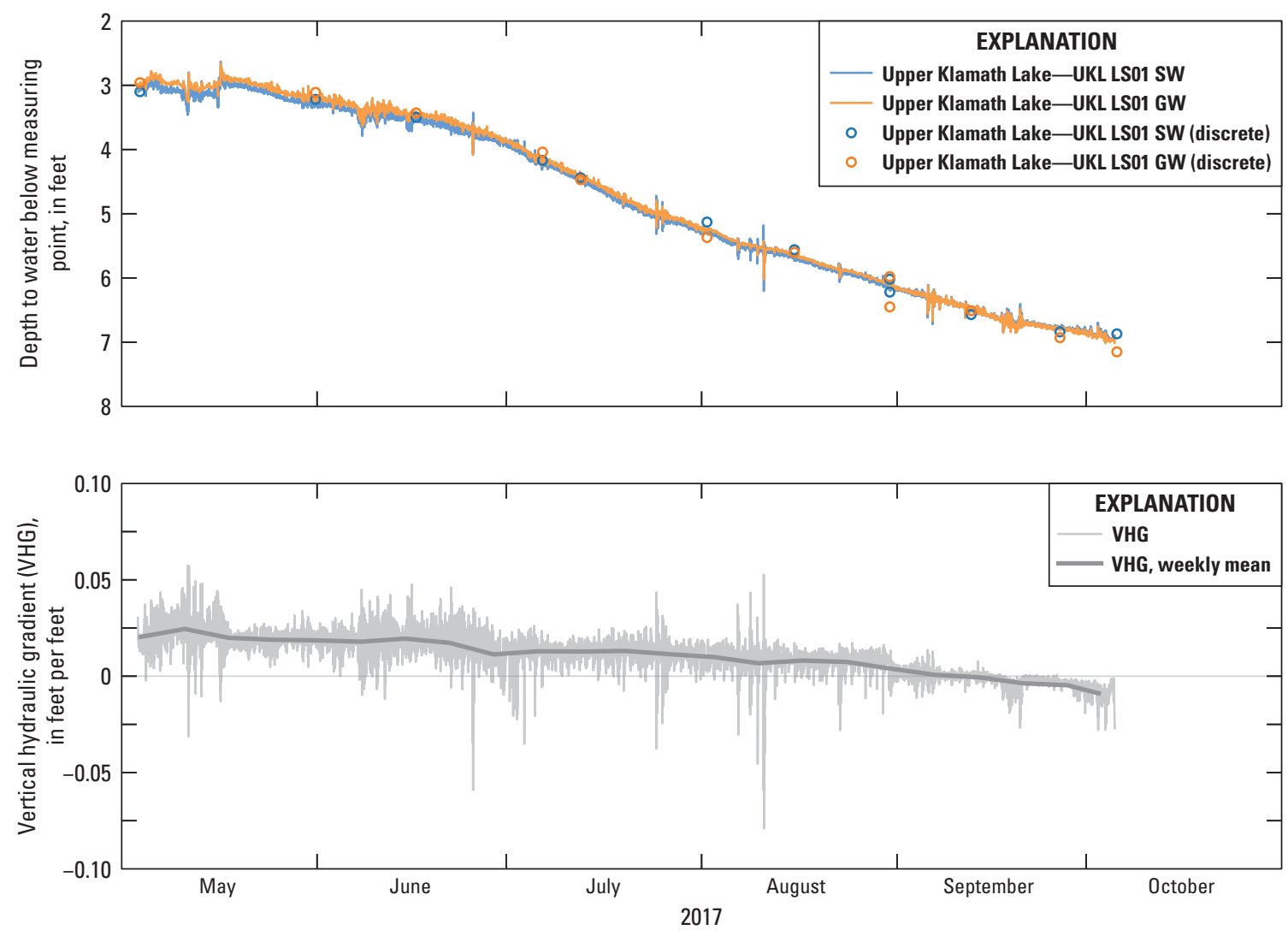

Figure 11. Graph showing groundwater and lake depth to water below the measuring point and vertical hydraulic gradient (VHG) at site LS01 in Upper Klamath Lake, Oregon, 2017. [Positive values of VHG indicate upward exchange (sediment to lake) and negative values indicate downward exchange (lake to sediment). Site location shown in figure 1] 

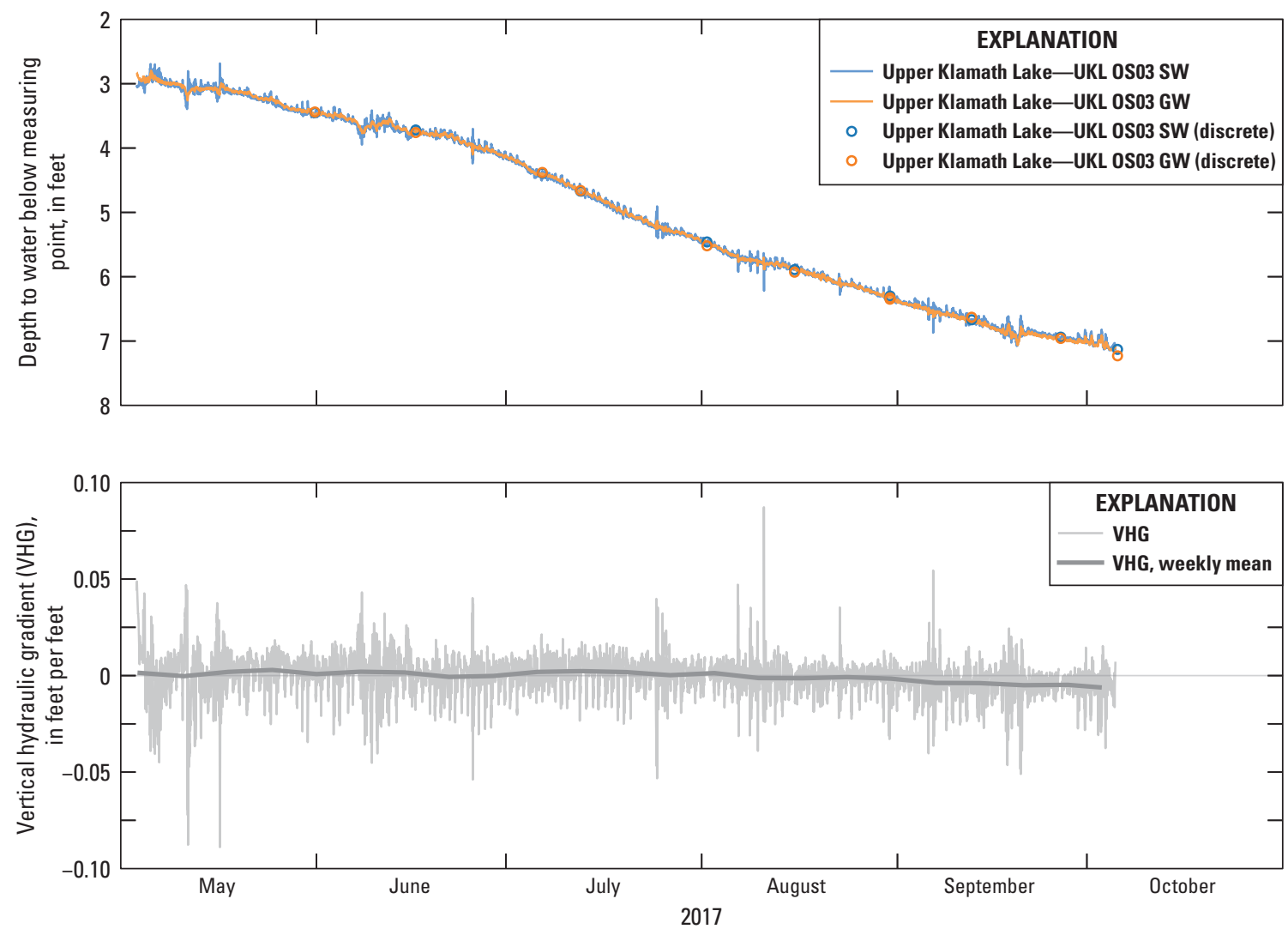

Figure 12. Graph showing groundwater and lake depth to water below the measuring point and vertical hydraulic gradient (VHG) at site OS03 in Upper Klamath Lake, Oregon, 2017. [Positive values of VHG indicate upward exchange (sediment to lake) and negative values indicate downward exchange (lake to sediment). Site location shown in figure 1] 

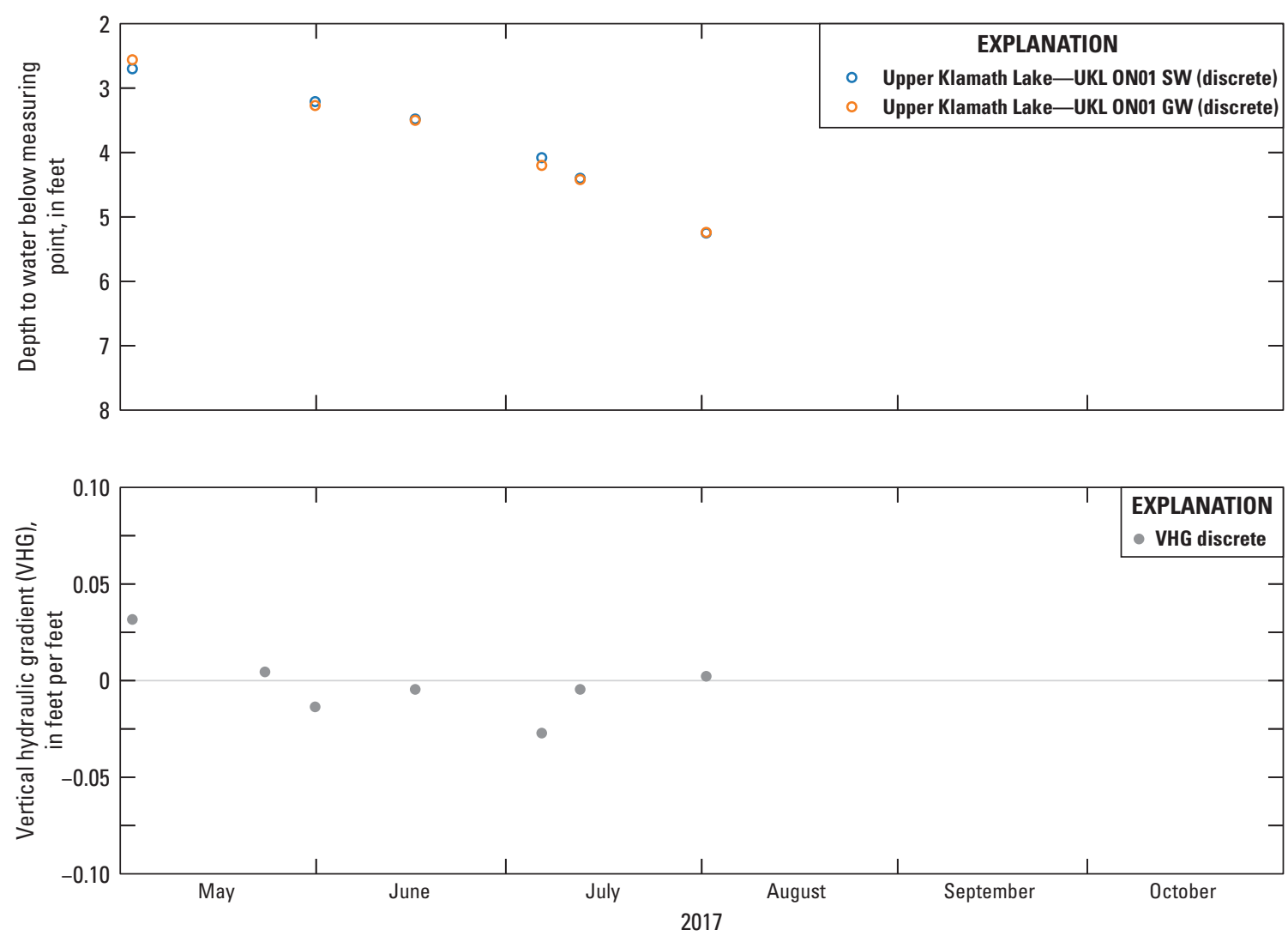

Figure 13. Graph showing groundwater and lake depth to water below measuring point data and vertical hydraulic gradient (VHG) at site ON01 in Upper Klamath Lake, Oregon, 2017. [Positive values of VHG indicate upward exchange (sediment to lake) and negative values indicate downward exchange (lake to sediment). No continuous data were available at $\mathrm{ONO1}$, therefore only discrete measurements of water level and the VHG values calculated using these measurements are presented in this study. Site location shown in figure 1]

\section{Conclusion}

Groundwater piezometers and lake stilling wells were deployed in paired sets at 10 locations in UKL during MayOctober 2017. Groundwater and lake levels were monitored in the paired piezometers and stilling wells and were used to calculate VHGs. Seven of the nine sites with continuous water-level data had study period mean VHG with a magnitude equal to or less than measurement uncertainty $( \pm 0.009 \mathrm{ft} /$ $\mathrm{ft}$ ), owing to the challenges associated with measuring small head differences in a wave-impacted lake system. Two nearshore littoral sites (LC03 and LS01) had positive (upward) study period mean VHG greater than measurement uncertainty and are likely locations of lakebed groundwater seepage. Instantaneous VHG data at all sites were highly dynamic and exhibited high-frequency changes in magnitude and direction. Although most instantaneous VHG values were within measurement uncertainty (VHG within $\pm 0.009 \mathrm{ft} / \mathrm{ft}$ ), individual instantaneous and weekly mean VHG values often exceeded this range. Water-level data and VHG estimates summarized in this report provide new information about the hydraulic conditions at the sediment-water interface in UKL. These data demonstrate that sediment-groundwater exchange in UKL is temporally dynamic over multiple time scales (hourly, daily, seasonally) and spatially heterogeneous. Additionally, the observed small rapid fluctuations in VHG, probably due to wave effects, may enhance mixing across the sedimentlake interface. Complete water-level and VHG datasets can be accessed in the U.S. Geological Survey data release by Corson-Dosch (2020).

\section{Acknowledgments}

The author gratefully acknowledges Sarah Blocker, Marty Erickson, and Justin VonTungeln with the U.S. Geological Survey (USGS) Klamath Falls Field Station and Adam Gibson and Bradley Smith with the USGS Portland Field Office for their considerable help with project field work. Jim Kuwabara, Jim Carter, Hedeff Essaid, Francis Parchaso, and Brent Topping with the USGS Water Resources Mission Area provided equipment and methodological insight that led to successful field deployment and data collection. Marshall Gannett, Steve Gingerich and Hank Johnson with the USGS 
Oregon Water Science Center provided thoughtful advice that improved this report and data quality. Tiffany Jacklin, Matt Johnson and Marc Stewart with the USGS Oregon Water Science Center are gratefully acknowledged for their help. The Klamath Falls Office of the U.S. Bureau of Reclamation also supported this work.

\section{References Cited}

Bortleson, G.C., and Fretwell, M.O., 1993, A review of possible causes of nutrient enrichment and decline of endangered sucker populations in Upper Klamath Lake, Oregon: U.S. Geological Survey Water-Resources Investigations Report 93-4087, 24 p. [Also available at https://pubs.er.usgs.gov/ publication/wri934087.]

Bureau of Reclamation, 2005, Natural flow of the upper Klamath River: Bureau of Reclamation Technical Service Center, Denver, Colorado, 77 p. plus attachments.

Cooper, R.M., 2004, Natural flow estimates for streams in the Klamath Basin: Oregon Water Resources Department OpenFile Report SW 04-001, 23 p. plus appendixes.

Corson-Dosch, N.T., 2020, Depth-to-water data and calculated vertical hydraulic gradient at the sediment-water interface in Upper Klamath Lake, Oregon, 2017: U.S. Geological Survey data release. [Also available at https://doi.org/10.5066/F7668CGD.]

Cunningham, W.L., and Schalk, C.W., comps., 2011, Groundwater technical procedures of the U.S. Geological Survey: U.S. Geological Survey Techniques and Methods 1-A1, $151 \mathrm{p}$.

Gannett, M.W., Lite, K.E., Jr., La Marche, J.L., Fisher, B.J., and Polette, D.J., 2007, Ground-water hydrology of the upper Klamath Basin, Oregon and California: U.S. Geological Survey Scientific Investigations Report 2007-5050, 84 p. [Also available at https://doi.org/10.3133/ sir20075050]

Gannett, M.W., Wagner, B.J., and Lite, K.E., Jr., 2012, Groundwater simulation and management models for the upper Klamath Basin, Oregon and California: U.S. Geological Survey Scientific Investigations Report 2012-5062, 92 p. [Also available at https://doi.org/10.3133/ sir20125062]

Hubbard, L.L., 1970, Water budget of Upper Klamath Lake, southwestern Oregon: U.S. Geological Survey Hydrologic Investigations Atlas HA-351

Johnson, D.M., Petersen, R.R., Lycan, D.R., Sweet, J.W., Neuhaus, M.E., and Schaedel, A.L., 1985, Atlas of Oregon Lakes: Corvallis, Oregon State University Press, 317 p.
Kann, J., and Walker, W.W., 2001, Nutrient and hydrologic loading to Upper Klamath Lake-Klamath Tribes Natural Resource Department: U.S. Bureau of Reclamation Cooperative Studies, 48 p.

Kann, J., Asarian, J.E., and Amand, St., A., 2015, Standardization and initial analysis of 1990-2013 phytoplankton and zooplankton data for Upper Klamath Lake (phase I): Prepared by Aquatic Ecosystem Sciences, LLC, for the Klamath Tribes Natural Resources Department, 100 p. plus appendixes.

Kuwabara, J.S., Topping, B.R., Lynch, D.D., Carter, J.L., and Essaid, H.I., 2009, Benthic nutrient sources to hypereutrophic Upper Klamath Lake, Oregon, USA: Environmental Toxicology and Chemistry, v. 28, no. 3, p. 516-524, https://doi.org/10.1897/08-207.1.

Kuwabara, J.S., Topping, B.R., Carter, J.L., Wood, T.M., Parchaso, F., Cameron, J.M., Asbill, J.R., Carlson, R.A., and Fend, S.V., 2012, Time scales of change in chemical and biological parameters after engineered levee breaches adjacent to Upper Klamath and Agency Lakes, Oregon: U.S. Geological Survey Open-File Report 2012-1057, 26 p. [Also available at https://doi.org/10.3133/ofr20121057]

Kuwabara, J.S., Topping, B.R., Carter, J.L., Carlson, R.A., Parchaso, F., Fend, S.V., Stauffer-Olsen, N., Manning, A.J., and Land, J.M., 2016, Benthic processes affecting contaminant transport in Upper Klamath Lake, Oregon: U.S. Geological Survey Open-File Report 2016-1175, 115 p. [Also available at https://pubs.er.usgs.gov/publication/ ofr20161175]

Leonard, A.R., and Harris, A.B., 1974, Ground water in selected areas in the Klamath Basin, Oregon: Oregon State Engineer Ground Water Report No. 21, 104 p.

Naranjo, R.C., Niswonger, R.G., Smith, D., Rosenberry, D., and Chandra, S., 2019, Linkages between hydrology and seasonal variations of nutrients and periphyton in a large oligotrophic subalpine lake: Journal of Hydrology (Amsterdam), v. 568, p. 877-890.

National Research Council, 2008, Hydrology, ecology, and fishes of the Klamath River Basin: Washington, D.C., The National Academies Press.

Oregon Department of Environmental Quality, 2002, Upper Klamath Lake drainage Total Maximum Daily Load (TMDL) and Water Quality Management Plan (WQMP). Oregon Department of Environmental Quality, 188 p.

Rosenberry, D.O., Sheibley, R.W., Cox, S.E., Simonds, F.W., and Naftz, D.L., 2013, Temporal variability of exchange between groundwater and surface water based on highfrequency direct measurements of seepage at the sedimentwater interface: Water Resources Research, v. 49, no. 5, p. 2975-2986. 
Schneider, R.L., Negley, T.L., and Wafer, C., 2005, Factors influencing groundwater seepage in a large, mesotrophic lake in New York: Journal of Hydrology (Amsterdam), v. 31 , no. $1-4$, p. $1-16$.

Snyder, D.T., and Morace, J.L., 1997, Nitrogen and phosphorus loading from drained wetlands adjacent to Upper Klamath and Agency lakes, Oregon: U.S. Geological Survey Water-Resources Investigations Report 97-4059, $67 \mathrm{p}$.

Stannard, D.I., Gannett, M.W., Polette, D.J., Cameron, J.M., Waibel, M.S., and Spears, J.M., 2013, Evapotranspiration from marsh and open-water sites at Upper Klamath Lake, Oregon, 2008-2010: U.S. Geological Survey Scientific Investigations Report 2013-5014, 66 p. [Also available at https://doi.org/10.3133/sir20135014]

Stauffer-Olsen, N.J., Carter, J.L., and Fend, S.V., 2017, Spatial and temporal variability in benthic invertebrate assemblages in Upper Klamath Lake, Oregon: Northwest Science, v. 91, no. 3, p. 257-271.

U.S. Fish and Wildlife Service, 2012, Revised recovery plan for the Lost River sucker (Deltistes luxatus) and shortnose sucker (Chasmistes brevirostris): U.S. Fish and Wildlife Service, Pacific Southwest Region, Sacramento, California. $\mathrm{xviii}+122 \mathrm{p}$.

Walker, W.W., Jr., 2001, Development of a phosphorus TMDL for Upper Klamath Lake: Oregon, Prepared for Oregon Department of Environmental Quality, 80 p.
Walker, W.W., Walker, J.D., and Kann, J., 2012, Evaluation of water and nutrient balances for the Upper Klamath Lake Basin in water years 1992-2010: Technical Report to the Klamath Tribes Natural Resources Department, 80 p. plus appendices.

Saiki, M.K., Monda, D.P., and Bellerud, B.L., 1999, Lethal levels of selected water quality variables to larval and juvenile Lost River and shortnose suckers: Environmental Pollution, v. 105, no. 1, p. 37-44.

Sullivan, A.B., Sogutlugil, I.E., Rounds, S.A., and Deas, M.L., 2013, Modeling the water-quality effects of changes to the Klamath River upstream of Keno Dam, Oregon: U.S. Geological Survey Scientific Investigations Report 2013-5135, 60 p. [Also available at https://pubs.usgs.gov/ sir/2013/5135 https://doi.org/10.3133/sir20135135]

Wood, T.M., Hoilman, G.R., and Lindenberg, M.K., 2006, Water-quality conditions in Upper Klamath Lake, Oregon, 2002-04: U.S. Geological Survey Scientific Investigations Report 2006-5209, 52 p. [Also available at https://doi.org/ $10.3133 / \operatorname{sir} 20065209]$

Wood, T.M., Wherry, S.A., Carter, J.L., Kuwabara, J.S., Simon, N.S., and Rounds, S.A., 2013, Technical evaluation of a total maximum daily load model for Upper Klamath and Agency Lakes, Oregon: U.S. Geological Survey Open-File Report 2013-1262, 84 p. [Also available at https://doi.org/10.3133/ofr20131262] 
Publishing support provided by the U.S. Geological Survey Science Publishing Network, Tacoma Publishing Service Center

For more information concerning the research in this report, contact the Director, Oregon Water Science Center

U.S. Geological Survey

2130 SW 5th Avenue

Portland, Oregon 97201

https://www.usgs.gov/centers/or-water 


\section{$\frac{\mathbb{3}}{3}$}

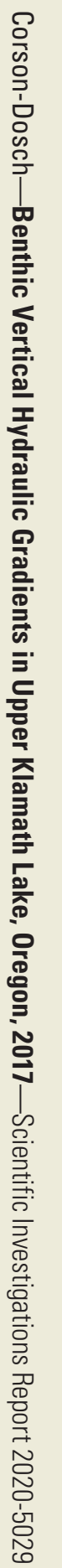

